\title{
HYDROGEOLOGY AND SIMULATION OF GROUND-WATER FLOW IN THE ALLUVIAL AQUIFER AT LOUISVILLE, KENTUCKY
}

By Mark A. Lyverse, J. Jeffrey Starn, and Michael D. Unthank

U.S. GEOLOGICAL SURVEY

Water-Resources Investigations Report 91-4035

Prepared in cooperation with the UNIVERSITY OF LOUISVILLE

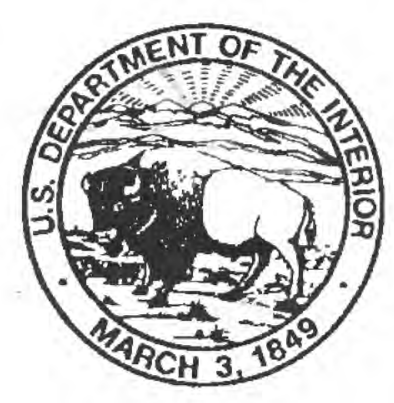

Louisville, Kentucky 


\section{U.S. DEPARTMENT OF THE INTERIOR BRUCE BABBITT, Secretary \\ U.S. GEOLOGICAL SURVEY \\ Gordon P. Eaton, Director}

For additional information write to:

District Chief

U.S. Geological Survey

District Office

2301 Bradley Avenue

Louisville, KY 40217
Copies of this report can be purchased from:

U.S. Geological Survey

Earth Science Information Center

Open-File Reports Section

Box 25286, MS 517

Denver Federal Center

Denver, CO 80225 


\section{CONTENTS}

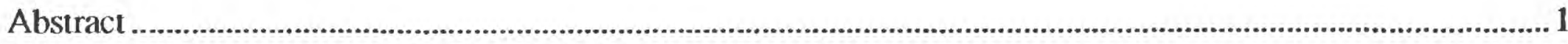

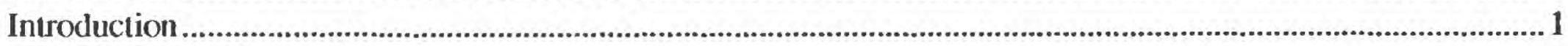

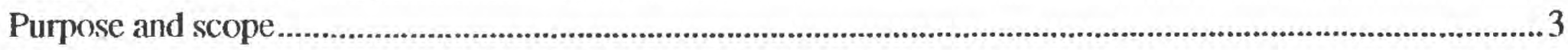

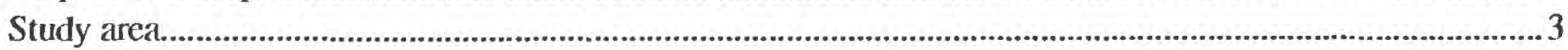

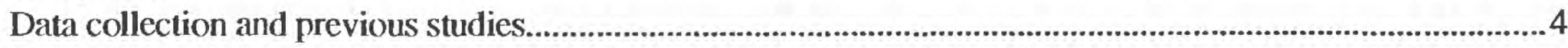

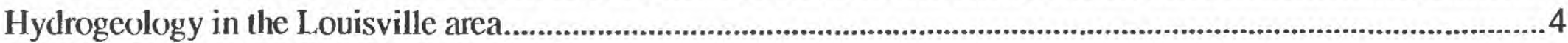

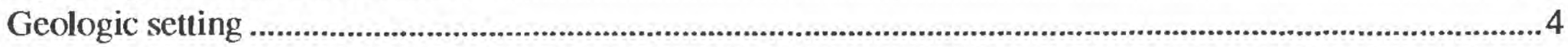

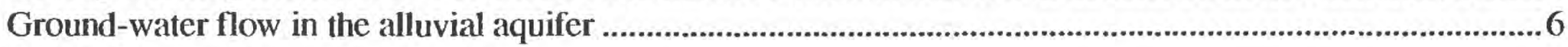

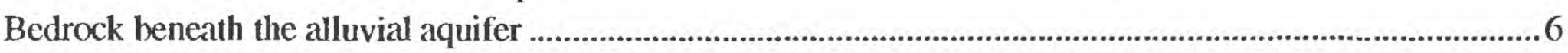

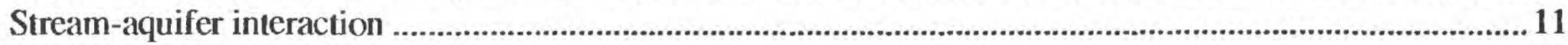

Small streams

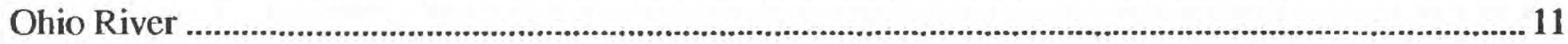

Natural recharge

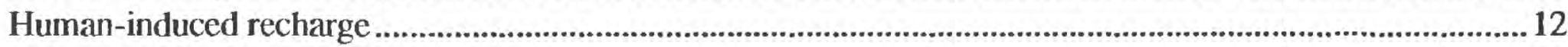

Water use and water-level fluctuation ....................................................................................................... 12

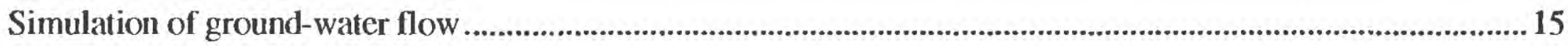

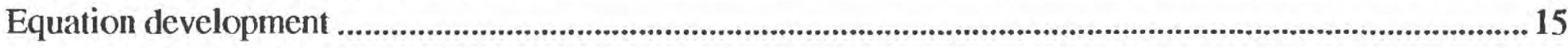

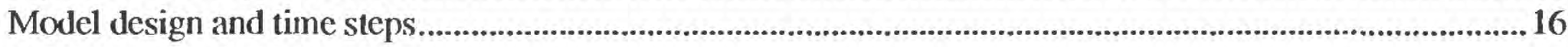

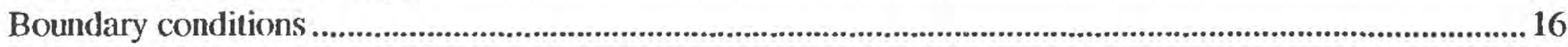

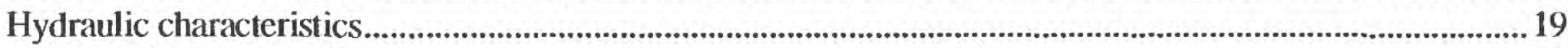

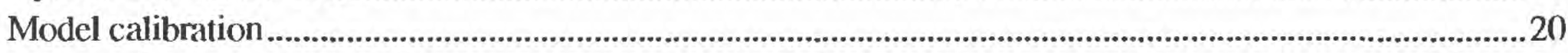

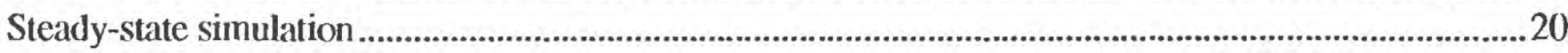

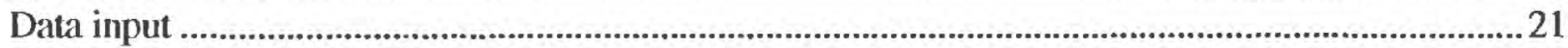

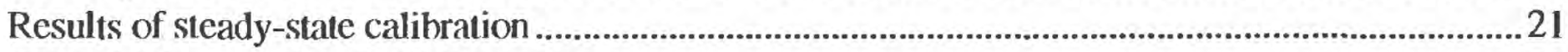

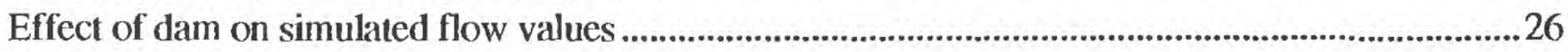

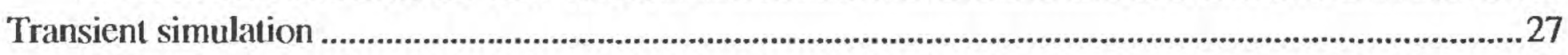

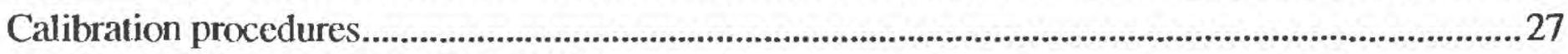

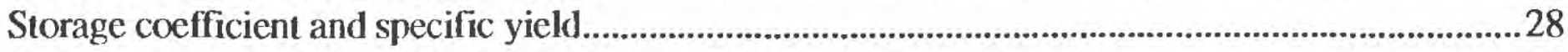

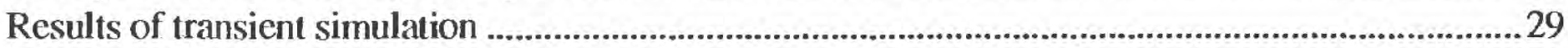

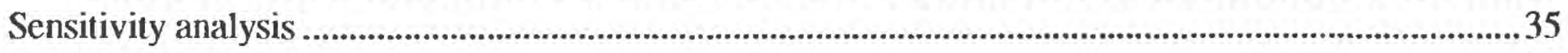

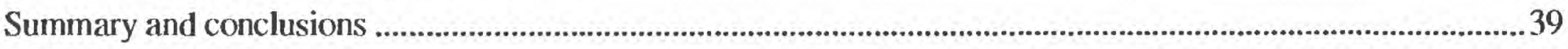

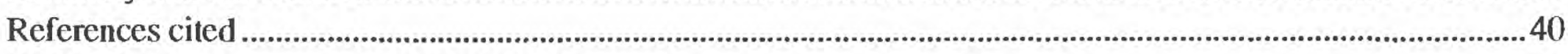

\section{FIGURES}

1. Map showing location of alluvial aquifer and observation-well network in the Louisville area,

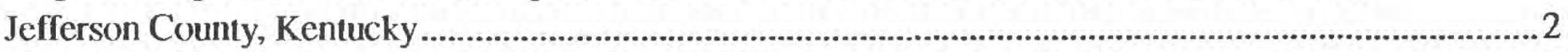

2. Generalized hydrogeologic cross section of the alluvial aquifer at Louisville..........................................5

3-5. Maps showing:

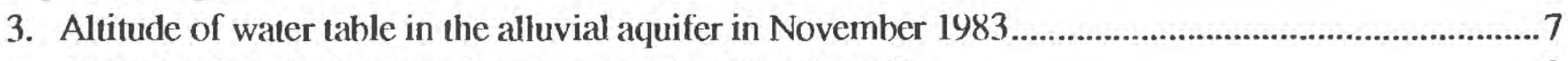

4. Altitude of the bedrock surface beneath the alluvial aquifer..............................................................9

5. Areas of the alluvial aquifer underlain by limestone or shale bedrock ............................................10

6. Graphs showing Ohio River stage at Louisville 1935-83 (a), average annual precipitation 1935-83 (b), and estimated average daily ground-water pumpage $1943-83$ (c) ......................................................... 13

7. Hydrographs of ground-water levels in the northern (a), central (b), and southern (c) parts of Jefferson County showing responses to river stage, ground-water pumpage, and to rainfall 
8-12. Maps showing:

8. Finite-element grid, aquifer-property zones, and lateral boundary conditions.

9. Aquifer-property zones and distribution of laboratory, aquifer-test, and model-simulated hydraulic conductivities

10. Distribution of model-simulated hydraulic conductivities of the limestone and shale bedrock .........22

11. Distribution of areal recharge that reaches the water table annually.............................................23

12a. Comparison of measured water levels and simulated water levels, November 1962 .......................24

12b. Comparison of measured water levels and simulated water levels. November 1983 ........................25

13a-e. Hydrographs showing measured and simulated water levels at selected sites, 1962-83 ...................30 -34

14. Graphs showing sensitivity of simulated heads to changes in selected variables used in the model ..........36

15. Graph showing sensitivity of simulated heads to changes in the specific yield used in the model............ 38

\section{TABLES}

1. Stratigraphic column of the geologic units in the Louisville area.

2. Simulated components of the ground-water budget for the alluvial aquifer under steady-state conditions, 1962 and 1983

\section{CONVERSION FACTORS}

\begin{tabular}{rll}
\hline Multiply & By & To obtain \\
acre & & \\
cubic foot $\left(\mathrm{ft}^{3}\right)$ & 0.4047 & hectare \\
cubic foot per second $\left(\mathrm{ft}^{3} / \mathrm{s}\right)$ & 0.028317 & cubic meter \\
cubic foot per day $\left(\mathrm{ft}^{3} / \mathrm{d}\right)$ & 0.28317 & cubic meter per second \\
cubic meter per day \\
foot $(\mathrm{ft})$ & 0.28317 & cubic meter per day per kilomeler \\
cubic foot per day per mile $\left.\left[\mathrm{ft}^{3} / \mathrm{d}\right) / \mathrm{mi}\right]$ & 0.01760 & meter \\
foot per day $(\mathrm{ft} / \mathrm{d})$ & 0.3048 & meter per day \\
gallon $(\mathrm{gal})$ & 0.3048 & liter \\
gallon per day $(\mathrm{gal} / \mathrm{d})$ & 3.785 & liter per day \\
inch $(\mathrm{in})$. & 3.785 & millimeter \\
mile $(\mathrm{mi})$ & 25.40 & kilometer \\
million cubic feet $\left(\mathrm{Mft}^{3}\right)$ & 1.609 & cubic meter \\
square mile $\left(\mathrm{mi}^{2}\right)$ & 28317 & cubic meter per day \\
million cubic feet per day $\left(\mathrm{Mft}^{3} / \mathrm{d}\right)$ & 28317 & square kilometer \\
\hline
\end{tabular}

Temperature in degrees Fahrenheit $\left({ }^{\circ} \mathrm{F}\right)$ can be converted to degrees Celsius $\left({ }^{\circ} \mathrm{C}\right)$ as follows:

$$
{ }^{\circ} \mathrm{C}=\left({ }^{\circ} \mathrm{F}-32\right) / 1.8
$$

Sea level: In this report "sea level" refers to the National Geodetic Vertical Datum of 1929 (NGVD of 1929) - a geodetic datum derived from a general adjustment of the first-order level nets of both the United States and Canada, formerly called "Sea Level Datum of 1929."

Use of trade names in this report is for identification purposes only and does not constitute endorsement by the U.S. Geological Survey. 


\title{
HYDROGEOLOGY AND SIMULATION OF GROUND-WATER FLOW IN THE ALLUVIAL AQUIFER AT LOUISVILLE, KENTUCKY
}

\author{
By Mark A. Lyverse, J. Jeffrey Starn, and Michael D. Unthank
}

\begin{abstract}
The alluvial aquifer at Louisville, Ky., lies in a valley eroded by glacial meltwater that was later partly filled with outwash sand and gravel deposits. The aquifer is primarily unconfined, and the direction of flow is from the adjacent limestone and shale valley wall toward the Ohio River and major pumping centers. Pumpage and water-level data indicate that the alluvial aquifer was in a steady-state condition in November 1962 and again in November 1983. Between these two dates, water-level data indicate a general rise in the water table.

A two-dimensional finite-element ground-water-flow model of the alluvial aquifer was calibrated for both the steady-state and the transient-state period 1962-83. The year 1962 represented a period in time when pumping was nearly three times that of 1983.
\end{abstract}

The simulated steady-state water budget for 1962 indicated that of the total recharge to the aquifer of 5.19 million cubic feet per day, 37.2 percent was flow from the river to pumped wells, 28.3 percent was recharge from rainfall, 19.7 percent was flow across the eastern valley wall, and 14.8 percent was upward flow from the bedrock. Discharge from the aquifer was to wells (68.9 percent) and to the Ohio River (31.1 percent).

The simulated steady-state water budget for 1983 indicated that of the total recharge to the aquifer of 4.11 million feet per day, 42.6 percent was recharge from rainfall, 18.2 percent was flow across the eastern valley wall, 17.8 percent was flow from the river to pumped wells, 15.6 percent was upward flow from the bedrock, and 5.8 percent was flow from septic systems.

The transient simulation resulted in an acceptable match between measured and simulated hydrographs. This gave additional confidence to the model calibration, choice of boundary conditions, and published values of specific yield. Both steady-state and transient-state models demonstrated that an important source of water needed to meet increased pumping requirements was induced flow from the Ohio River.

\section{INTRODUCTION}

A large area of the city of Louisville in Jefferson County, Ky., lies in the alluvial valley of the Ohio River (fig. 1). The alluvium consists of unconsolidated glacial outwash sand and gravel of the Pleistocene and Holocene Ages, overlain by silt and clay of Holocene Age. This alluvium forms a productive, areally restricted aquifer that is hydraulically connected to the Ohio River. 


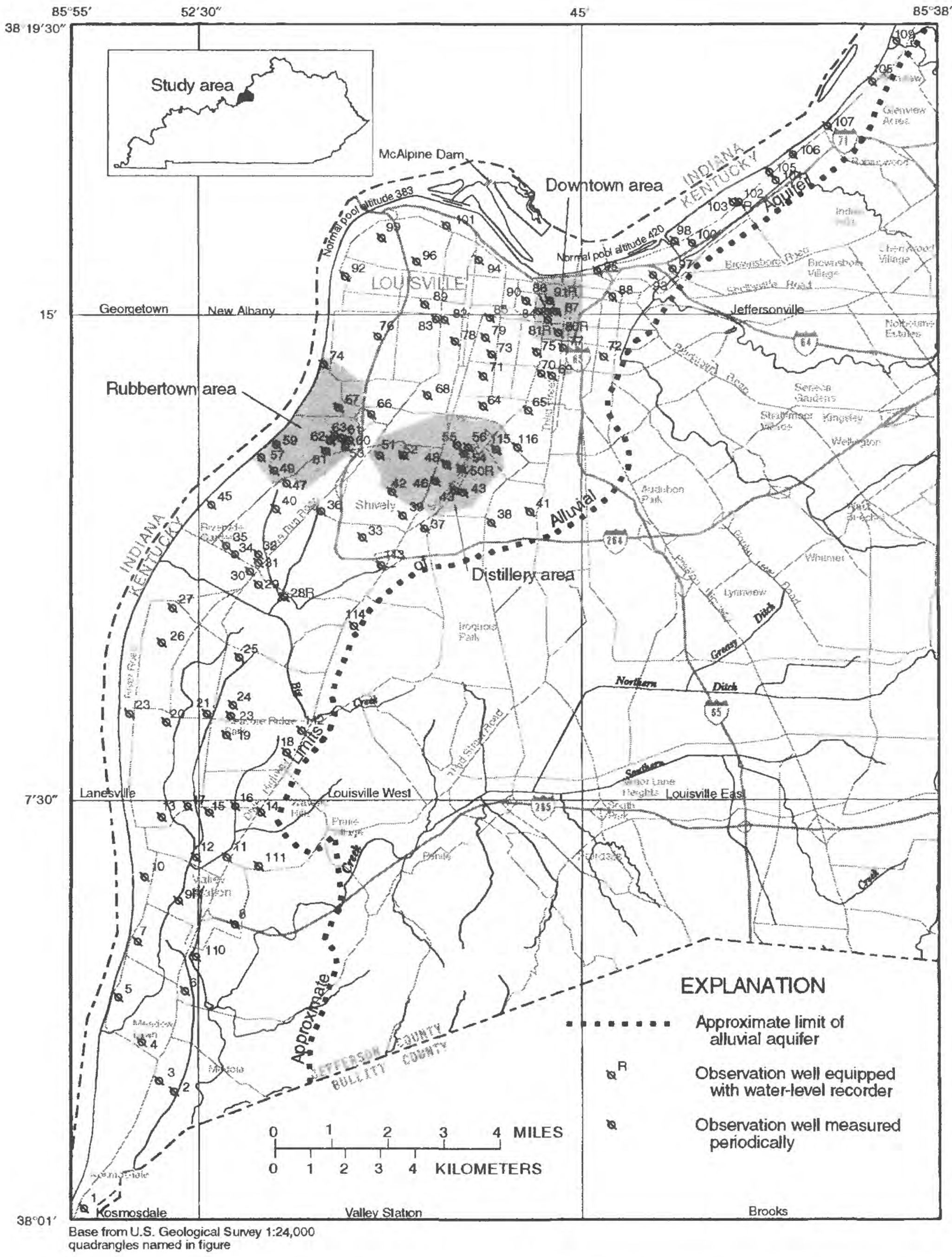

Figure 1. Location of alluvial aquifer and observation-well network in the Louisville area, Jefferson County, Kentucky. 
Many industries were located in the Louisville area because of the capability of the alluvial aquifer to yield large quantities of water. Also, the temperature and quality of ground water are ideally suited for many industrial processes. During World War II, the expansion or construction of industrial facilitics (particularly in the chemical, alcohol, and rubber industries) resulted in overdevelopment of the alluvial aquifer. Overdevelopment was accompanied by a substantial lowering of the water table (Rorabaugh and others, 1953). The decline in water levels necessitated lowering pump intakes, decpening wells. reducing withdrawals, and artificial recharge in some of the heavily pumped industrial wellficlds (Rorabaugh, 1949).

Major ground-water withdrawals were reduced gradually after World War II, and during the 1960's and 1970 's, water levels in the alluvial aquifer recovered. The rising water-level trend hegan to slow in 1979 , and by 1981 , the water table seemed to stabilize except for seasonal fluctuations in response to precipitation and river stage (Whitesides and others, 1983).

In 1984, the State of Kentucky began to require detailed permit applications for ground-water withdrawals of $10,000 \mathrm{gal} / \mathrm{d}$ or more. This newly implemented permitting system coupled with a renewed interest in the usc of ground water for heating and cooling brought about a nced for an improved understanding of the aquifer system and for tools to effectively manage the aquifer.

\section{Purpose and Scope}

This report describes the results of an investigation to (1) refine the understanding of the hydrology of the alluvial aquifer in the Jefferson County area and (2) develop a ground-water-flow model capablc of simulating regional ground-water flow in the alluvial aquifer in the Louisville area.

These objectives were met by (1) reviewing available literature, (2) collecting and interpreting hydrologic and lithologic data, (3) updating water-use records. (4) measuring water levcls. (5) constructing or revising pertinent hydrogeologic maps, and (6) constructing and calibrating a two-dimensional groundwater-flow model. The study was linited to the alluvial aquifer in Jefferson County, Ky., with emphasis on the Louisville area.

\section{Study Area}

The study area includes about $85 \mathrm{mi}^{2}$ of the alluvial aquifer along the south side of the Ohio River in Jefferson County (fig. 1). The central part of the study area and the widest part of the aquifer is primarily a commercial and industrial area. Land use in the remainder of the study area is residential except for the primarily rural southwestern part. The aquifer becomes more narrow beyond the study arca north and south along the Ohio River.

The population of Louisville and surrounding metropolitan areas was 760,000 in 1980 (U.S. Department of Commerce, 1980). The climate is temperate, and the average annual precipitation from 1932 to 1987 (U.S. Department of Commerce, 1987) was 43.6 inches per year (in/yr). Average annual discharge of the Ohio River at Louisville from 1928 to 1987 (U.S. Geological Survey. 1987, p. 93) was $115,700 \mathrm{ft}^{3} / \mathrm{s}$, which equates to $17.23 \mathrm{in} / \mathrm{yr}$ over the drainage basin. 


\section{Data Collection and Previous Studies}

The alluvial aquifer beneath Louisville has been studied extensively, and previously collected data were available for use in this study. Some new data were collected (six observation wells were drilled), to confirm earlier findings that were based on inadequate data.

The geology of Jefferson County has been described by Hamilton (1944), Rorabaugh (1946a and 1946b), and Bell (1966). The configuration of the bedrock surface and alluvial bedrock contacts were defined by using structure maps drawn by Kepferle (1972, 1974a, and 1974b). Available lithologic data include fence diagrams of alluvial deposits along the Ohio River taken primarily from the Hydrologic Investigations Atlas by Price (1964a and 1964b). Investigations by Guyton and Sublett (1944) and by Rorabaugh (1946a, 1946b, 1948, 1949, and 1956) were invaluable in documenting the decline in water levels during World War II and in conceptualizing the overall ground-water flow system and water budget. Also, Guyton (1944) documented occurrence of artificial recharge to the aquifer in the Louisville area. A study by Rorabaugh (1956) to determine the quantity and quality of ground water northeast of the city produced the basic theory and equations related to induced infiltration of river water into aquifers. Palmquist and Hall (1960) described ground-water availability in Jefferson, Bullitt. and Oldhan counties.

Significant reduction of ground-water withdrawals in the 1960's and the subsequent rise of the groundwater table in the mid- to late-1970's was documented first by Kernodle and Whitesides (1977) and later by Whitesides and others (1983). Recent ground-water-level conditions were reponed by Faust and Lyverse (1987) and by Faust and Lyons (1989). A compilation of selected references on ground-water resources and geohydrology of the Louisville area (1944-93) was published by Starn and Mull (1994).

Historical ground-water data were obtained primarily from publications of the U.S. Genlogical Survey (USGS). Some of the data used in this study, however, were taken from field measurement notes and other unpublished data maintained on file in the USGS office in Louisville, Ky.

Soil characteristics for the study area were described by the U.S. Department of Agriculture (1966). These included infiltration properties of the alluvial clay, silt, and sand layers overlying the alluvial aquifer. Metropolitan areal distribution of land use, vegetal cover, and septic tank recharge rates in unsewered areas were obtained from the Louisville and Jefferson County Metropolitan Sewer District (MSD).

\section{HYDROGEOLOGY IN THE LOUISVILLE AREA}

\section{Geologic Setting}

The rocks underlying the alluvial aquifer in the Louisville area are primarily limestones and shales of the Silurian and Devonian Ages (fig. 2). The formations are fairly uniform in thickness and dip about $40 \mathrm{ft} / \mathrm{mi}$ to the west and southwest.

During the Pleistocene epoch, glacial meltwater eroded a deep valley through the present location of Louisville. The valley floor reached a depth of about $120 \mathrm{ft}$ below the present land surface. The Pleistocene valley is about $0.25 \mathrm{mi}$ wide northeast of Louisville, 6 to $7 \mathrm{mi}$ wide at Louisville, and gradually narrows to about $1.5 \mathrm{mi}$ at the southwestem corner of Jefferson County. The altitude of the main channel in bedrock is 340 to $350 \mathrm{ft}$ above sea level in Jefferson County. 


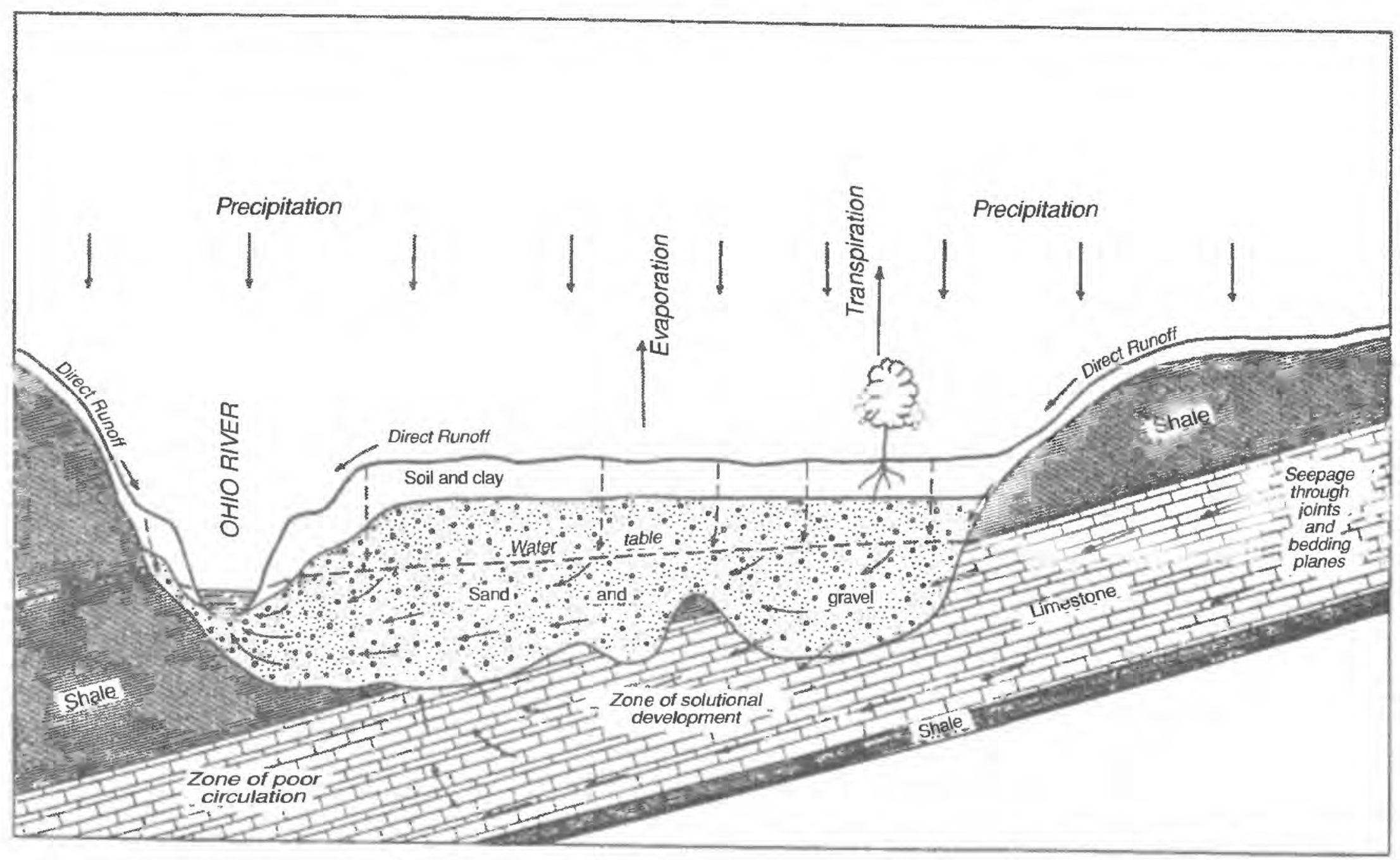

From Rorabaugh and others, 1953

Figure 2. Generalized hydrogeologic cross section of the alluvial aquifer at Louisville. 
The Pleistocene channel was later filled to near its present level with glacial outwash sand and gravel. The northern and western edge of the sand and gravel deposits in the Louisville area are hordered by the Ohio River. The river is decply entrenched in the Louisville area, although some out wash material occurs between the river bottom and the top of the bedrock (fig. 2). The outwash material has an average thickness of about $100 \mathrm{ft}$ and is overlain by Ohio River floodplain deposits of clay, silt, and fine sand that may be as much as $40 \mathrm{ft}$ thick in some areas.

\section{Ground-Water Flow in the Alluvial Aquifer}

Depending on water-level altitudes and thickness of the overlying silt and clay cap, the alluvial aquifer can be confined or unconfined. The confined condition occurs only in a small part of the study area. and then primarily under non-stressed conditions. Although the glacial out wash is heterogeneous, aquifer tests indicate that it generally functions as a homogeneous unit if the cone of depression resulting from pumping a well expands to a large part of the aquifer (Walker, 1961).

Under natural conditions, regional ground-water flow is predominately horizontal and from the alluvium/bedrock boundary (hereinafter referred to as valley wall) toward the Ohio River (fig. 3). Groundwater withdrawals in one area caused the water-level contours to deviate from their normal paltern parallel to the river.

Recharge to the alluvial aquifer is from vertical percolation of precipilation, outflow from the valley wall to the alluvium (except where localized variations may reflect a reversed condition), upward vertical flow from the underlying bedrock, and infiltration from the Ohio River. Infiltration of water from the Ohio River to the aquifer occurs during high-river stages or when pumping wells along the river lowers the water table below the stage of the river. Discharge from the aquifer is by flow to the Ohio River and wells.

\section{Bedrock Beneath the Alluvial Aquifer}

Bedrock beneath the glacial outwash in the Louisville area is predominantly Silurian and Devonian limestones and shales (table 1). The principal water-bearing bedrock formations are the Louisville, Jeffersonville, and Sellersburg Limestones. These subcrop underneath the alluvial aquifer in the northeastern part of the study area and in the deeper parts of glacial valley in the central part of the study area. The New Albany Shale underlies the alluvial aquifer in the southwestem part of the study area and in the higher parts of the Pleistocene valley in the central part of the study area.

Altitudes at the top of the bedrock surface beneath the alluvial aquifer were compiled by Price (1964a and 1964b) (fig. 4). These altitudes were important to this study because this surface is, in effect, a lower boundary for the alluvial aquifer. Several areas of high bedrock altitude can be seen on figure 4 . The glacial outwash is thinner and less ground water is available in these areas.

Rorabaugh and others (1953, p. 6) presented a generalized diagram of the local hydrologic system (fig. 2) that depicts water movement through the zones of solutional development in the bedrock. Most of the water movement occurred where joints and bedking planes in the limestones which underlie the valley fill have been enlarged by the dissolution of limestone. The areas underlain by limestone and shale are shown in figure 5. Rorabaugh noted that wells completed in the limestone bedrock generally had heads I to $2 \mathrm{ft}$ higher than nearby wells completed in the alluvial aquifer, indicating upward flow from the bedrock to the alluvium. 


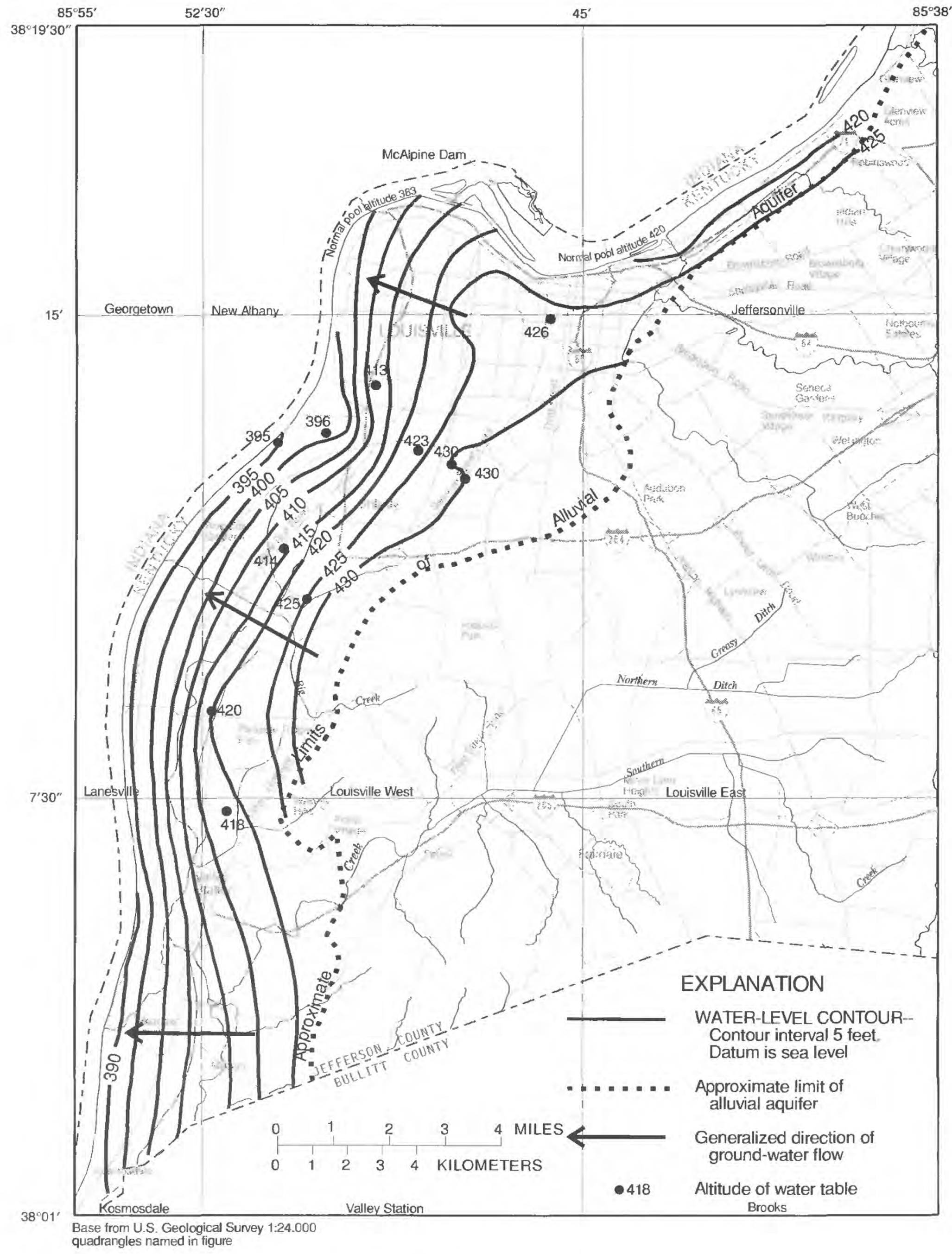

Figure 3. Altitude of water table in the alluvial aquifer in November 1983. 
Table 1. Stratigraphic column of the geologic units in the Louisville area

\begin{tabular}{|c|c|c|c|c|}
\hline System & Series & Formation & $\begin{array}{l}\text { Thickness, } \\
\text { in feet }\end{array}$ & Lithology and remarks \\
\hline Quaternary & $\begin{array}{l}\text { Holocene and } \\
\text { Pleistocene }\end{array}$ & Alluvium & $0-130$ & $\begin{array}{l}\text { Glacial outwash, sand, and } \\
\text { gravel overlain by silt and } \\
\text { clay. Represents the primary } \\
\text { aquifer in the Louisville area. }\end{array}$ \\
\hline \multirow[t]{5}{*}{ Mississippian } & Upper Mississippian & $\begin{array}{l}\text { Salem Limestone } \\
\text { Harrodsburg Limestone }\end{array}$ & $\begin{array}{l}50+ \\
40+\end{array}$ & \multirow{5}{*}{$\begin{array}{l}\text { Limestones, siltstones, and } \\
\text { shales that are generally } \\
\text { topographically above the } \\
\text { alluvium except in southern } \\
\text { Jefferson County. In otlier } \\
\text { words, the Ohio River Valley } \\
\text { was cut through Mississippian } \\
\text { rocks, and the alluviuin } \\
\text { directly overlies mustly } \\
\text { Devonian and Silurian tocks in } \\
\text { the Louisville area. }\end{array}$} \\
\hline & Lower Mississippian & Muldraugh Member & $75-95$ & \\
\hline & & Floyds Knob Bed & 1-9 & \\
\hline & & Nancy Member & $200-220$ & \\
\hline & & New Providence Shale Member & $175-205$ & \\
\hline \multirow[t]{2}{*}{ Devonian } & Upper Devonian & New Albany Shale & $100+$ & $\begin{array}{l}\text { Shale that underlies much of } \\
\text { the alluvial aquifer in the } \\
\text { Louisville area as shown in } \\
\text { figure } 5 \text {. }\end{array}$ \\
\hline & Middle Devonian & $\begin{array}{l}\text { Sellersburg Limestone } \\
\text { Jeffersonville Limestone }\end{array}$ & $\begin{array}{l}0-22 \\
0-30\end{array}$ & $\begin{array}{l}\text { Limestone that, along with the } \\
\text { underlying Silurian rocks, } \\
\text { represents part of the } \\
\text { limestone bedrock beneath the } \\
\text { alluvial aquifer as shown in } \\
\text { figure } 5 \text {. }\end{array}$ \\
\hline \multirow[t]{2}{*}{ Silurian } & Middle Silurian & $\begin{array}{l}\text { Louisville Limestone } \\
\text { Waldron Shale } \\
\text { Laurel Dolomite } \\
\text { Osgood Formation }\end{array}$ & $\begin{array}{c}45-100 \\
10+ \\
40+ \\
30\end{array}$ & $\begin{array}{l}\text { Limestone with minor } \\
\text { amounts of dolomite and } \\
\text { shale. These rocks, along with } \\
\text { the overlying Devonian } \\
\text { limestones, represent the }\end{array}$ \\
\hline & Lower Silurian & Brassfield Dolomite & $4+$ & $\begin{array}{l}\text { limestone bedrock beneath the } \\
\text { alluvial aquifer as shown in } \\
\text { figure } 5 \text {. The Louisville } \\
\text { Limestone, because of its } \\
\text { thickness, has the largest } \\
\text { contact with the overlying } \\
\text { alluvium and is also the best } \\
\text { hedrock aquifer beneath the } \\
\text { alluvium. }\end{array}$ \\
\hline
\end{tabular}




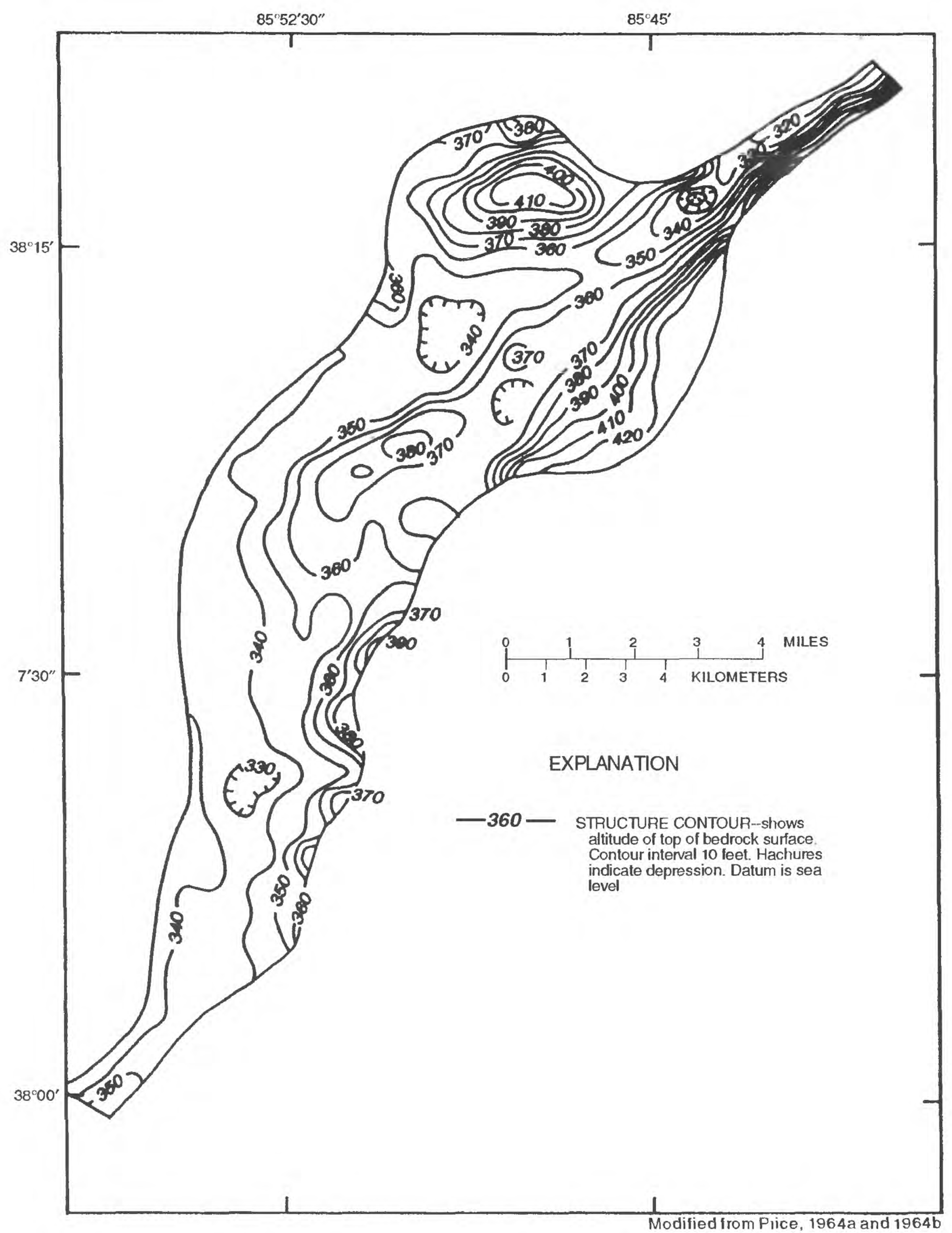

Figure 4. Altitude of the bedrock surface beneath the alluvial aquifer. 


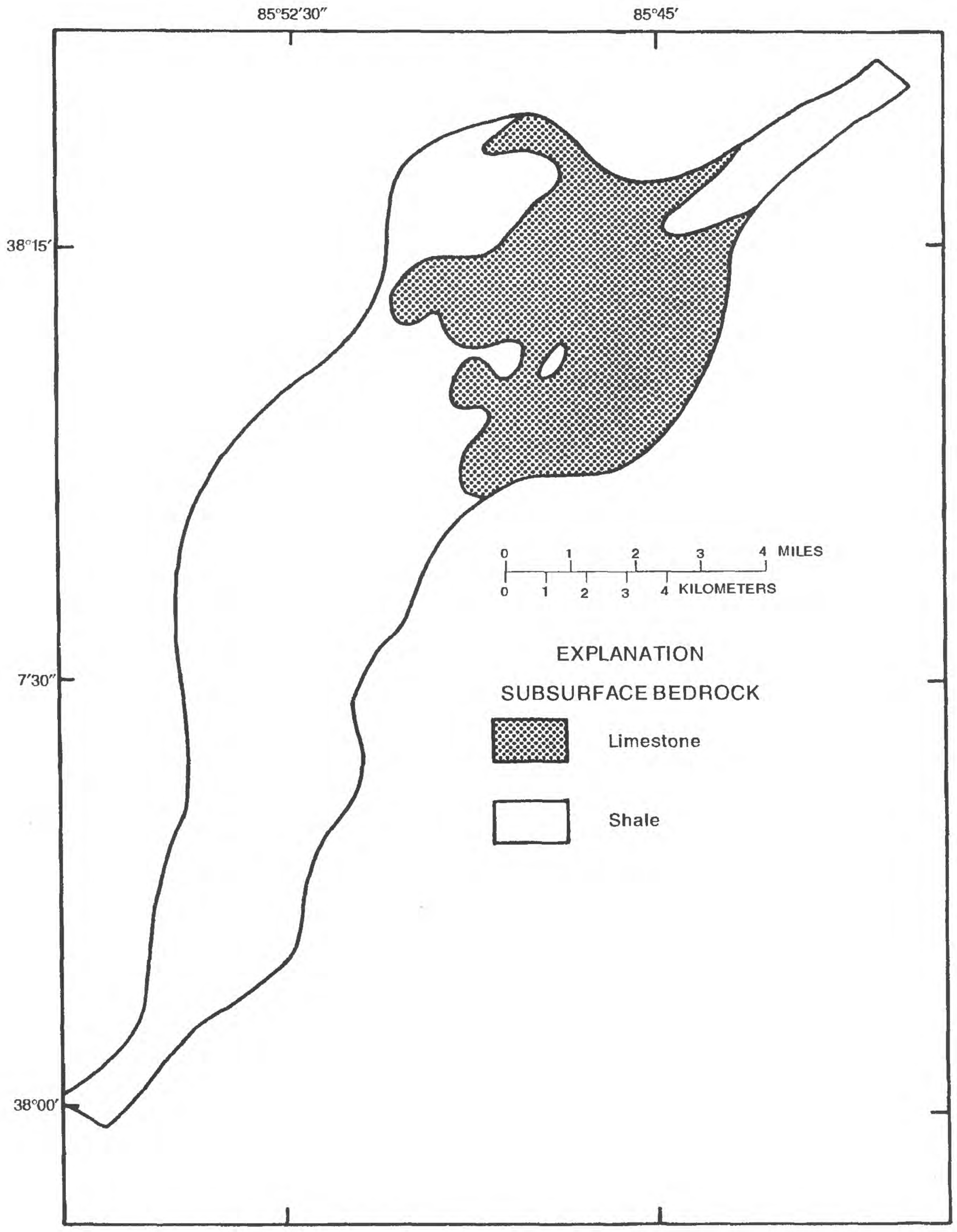

Figure 5. Areas of the alluvial aquifer underlain by limestone or shale bedrock.

10 Hydrogeology and SImulation of Ground-Water Flow in the Alluvial Agulfer at Louisville, Kentucky 


\section{Stream-Aquifer Interaction}

\section{Small Streams}

Two small streams, Pond Creck in the southem and westem parts of the County and Beargrass Creek in the north-central part (fig. 3), provide most of the surface-water drainage in the study area. These streams do not have adequate flow for dependable supplies and may cease to flow for a few days or weeks during dry periods of summer and fall. Because of the small amount of flow, the exchange of water between Pond and Beargrass Creeks and the alluvial aquifer was considered negligible in terms of the overall water budget of the aquifer.

\section{Ohio River}

McAlpine Dam (fig. 3) at Louisville creates a pool that extends upstream for a distance of $75 \mathrm{mi}$ to Markland Dam on the Ohio River. The water level in the pool is normally maintained at about $420 \mathrm{ft}$ above sea level at Louisville. The pool below the dam at Louisville is maintained at an altitude of about $383 \mathrm{ft}$ by Cannelton Dam, 114 mi downstream of Louisville.

The comection between the streambed of the Ohio River and the alluvial aquifer affects the distribution of water in the study area. The rate of water moving through the streambed is proportional to its hydraulic conductivity. A previous study (Rorabaugh, 1946b, p. 36) indicated that the hydraulic conductivity between the streambed and the aquifer varies along the river and depends on the thickness of a layer of clay and fine sand. Flood infiltration tests done by Rorabaugh delineated the areas of most effective hydraulic connection between the river and aquifer as being along the northeast reach of the study area and south of the area near Lee's Lane in the southern section. In between these two areas, the streambed is less permeable. In the northern part of this intervening arca, shale bedrock is above the normal pool altitude, and along the western part of this reach, the movement of water is restricted by a clay bed along the bank of the river (Rorabaugh, 1949, p. 17).

\section{Natural Recharge}

The alluvial aquifer is recharged under natural conditions from the following sources: (1) subsurface flow from the consolidated rocks along the valley walls and upward from the limestone bedrock; (2) direct infiltration of precipitation through the floodplain; (3) flow from small streams; and (4) temporary recharge occurring at times when the stage of the Ohio River is higher than adjacent ground-water levels, resulting in flow from the river to the aquifer. Rainfall varies from year to year and thus recharge to the alluvial aquifer also varies.

Rorabaugh (1949, p. 20) estimated flow through the valley wall to be about $13.40\left(\mathrm{fi}^{3} / \mathrm{d} / \mathrm{mi}\right.$ of valley wall southwest of Louisville, about $26,700 \mathrm{ft}^{3} / \mathrm{d} / \mathrm{mi}$ northeast of the city, and at least $26,700 \mathrm{ft}^{3} / \mathrm{d} / \mathrm{mi}$ between Beargrass Creek and Shively. The high rates between Beargrass Creck and the Shively area were due to the steeper ground-water gradients and limestone bedrock in this area. Walker (1961) used Darcy's equation to calculate inflow from the consolidated strata in the southwest part of Louisville to be $18,700 \mathrm{ft}^{3} / \mathrm{d} / \mathrm{mi}$ of valley wall. To obtain this estimate, Walker used a hydraulic conductivity of $200 \mathrm{ft} / \mathrm{d}$, a gradient of $2 \mathrm{ft} / \mathrm{mi}$, and a saturated thickness of $45 \mathrm{ft}$.

Upward flow from the hedrock to the alluvial aquifer is probably considerahle in areas underlain by limestone bedrock, but of only minor imporlance in areas of shale bedrock. The volume of flow from the hedrock was not calculated in previous studies because the extent of the connection between the limestone and outwash material was unknown. 
Recharge resulting from rainfall on the floodplain was estimated from detailed hydrologic studies in arcas unaffected hy pumping or floods to be ahoul 6 in/yr (Rorabaugh, 1949, p. 20). Rorabaugh also noted that the recharge from rainfall was considerably less than 6 in. in urban areas because water was urained to sewers from buildings and paved streets. Walker (1961) used a mass-balance equation to determine that approximatcly $5 \mathrm{in} / \mathrm{yr}$ of rain infiltrated the aquifer in areas unaffected by pumping. Both of these infiltration studies took place in rural areas.

For the purpose of this model, flow to the aquifer from small streams and flow into the aquifer during periods of high Ohin River stages under unst ressed conditions were considered to be temporary and snall. Also, isolation of these components was beyond the scope of the current study.

\section{Human-Induced Recharge}

In addition to recharge to the aquifer under nalural conditions, recharge is added to the ground-water system through human-related activities. These activities include recharge by induced flow from the Ohio River through its bank to produclion wells near the river and by accretion of sewage effluent to the water table in unsewered areas where septic systens are used (Kernodle and Whitesides, 1977).

The hydraulic connection between the Ohio River and the alluvial aquifer allows high-capacity wells near the river to induce large amounts of water to flow through the banks and bed of the river. Estimates of available supply through induced infiltration have been made in previous investigations (Rorabaugh 1949, 1956). In a 3- $\mathrm{mi}^{2}$ area between Beargrass Creek and Harrods Creek (northcast of Louisville), Rorabaugh estimated the maximum dependable yield which could be developed under conditions of lowest river level and an average temperature of $64^{\circ} \mathrm{F}$ would be at least $37.4 \mathrm{Mft}^{3} / \mathrm{d}$.

Recharge to the alluvial aquifer also occurs from leaky septic systems in unsewered residential areas (Kernodle and Whitesides, 1977). These areas are primarily in the south and southwestern parts of the study area. Recharge in these areas was estimated using data compiled by the U.S. Environmental Protection Agency (1981). Septic-tank inflow was added to the system each year from 1970 to 1983. The areas receiving seplic tank inflow were relatively undeveloped prior to 1970. Recharge in unsewered areas was calculated using total-flow billing records (for these areas) from the Louisville Water Company. Flow values were then corrected by assuming wastewater flow was 67 percent of total water supplied (assuming consumptive use of 33 percent) and assigning resulting values of flow to the unsewered areas; thus, total recharge to the alluvial aquifer from sewer effluent was approximately $240,\left(100 \mathrm{ft}^{3} / \mathrm{l}\right.$, or approximately 6 percent of the total recharge to the aquifer for 1983.

\section{Water Use and Water-Level Fluctuation}

Stages of the Ohio River can be directly related to precipilation (figs. 6a and 6b). Ground-water pumpage from the alluvial aquifer in Jefferson County as a source of water peaked in the early-1940's when an estimated $8 \mathrm{Mft}^{3} / \mathrm{d}$ was used (fig. $6 \mathrm{c}$ ). Reduced economic growth and a sewer-usage lax levied on ground-water discharges in 1947 were a few of the reasons ground-water wilhdrawals decreased. Pumpage and water levels were relatively stable until the mid-1960's when water levels began to rise. Ground-water levels continued to rise until 1979 when they again stabilized (figs. 7a-7c). In 1980, ground-waler levels reached an apparent equilibrium level. Measurements of ground-water levels and their response to pumping and rainfall have becn made in the study area for ncarly 50 years. 

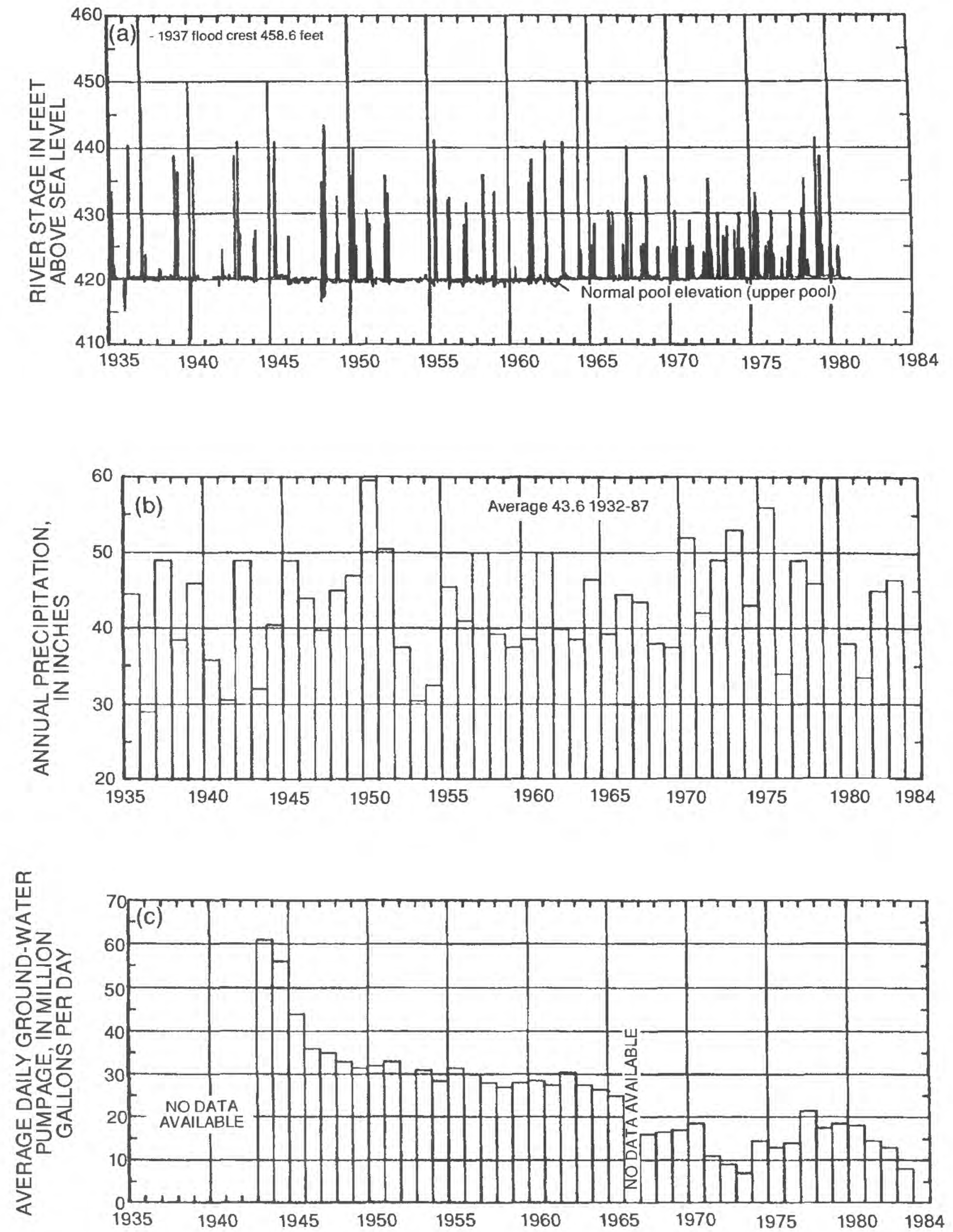

Figure 6. Ohio River stage at Louisville 1935-83 (a), average annual precipitation 1935-83 (b), and estimated average daily ground-water pumpage $1943-83$ (c). 

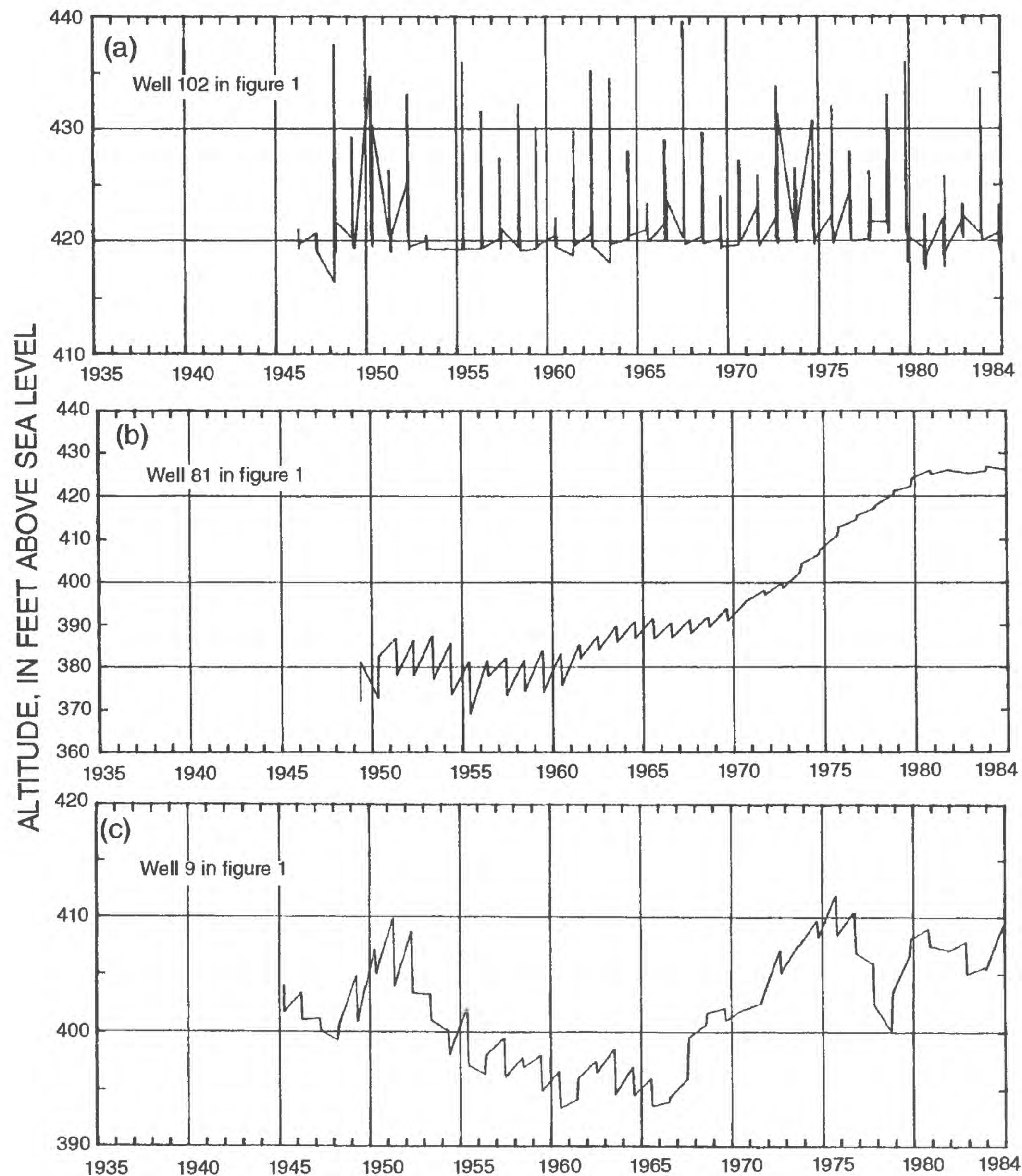

Figure 7. Ground-water levels in the northern (a), central (b), and southern (c) parts of Jefferson County showing responses to river stage, ground-water pumpage, and to rainfall. 
The hydrograph of stage in the Ohio River (fig. 6a) showed rapid increases of short duration that were similar in character to water levels in a well near the river (fig. 7a). This relation was a result of the high degree of hydraulic connection between the river and the aquifer. Water levels in wells further from the river (fig. 7b) showed a steady rise from the period 1962 to 1983 in response to the decrease in groundwater withdrawal from the aquifer (fig. $6 \mathrm{c}$ ). Water levels in wells outside the areas of pumping (fig. 7c) showed that water levels fluctuated, probably in response to rainfall conditions. Faust and Lyverse (I987) examined hydrographs (1977-87) from wells outside the areas of pumping to show that water levels fluctuated approximately 2 to 3 ft seasonally and that no trend existed during 1977-87.

\section{SIMULATION OF GROUND-WATER FLOW}

\section{Equation Development}

The model of the alluvial aquifer in this report was based on the numerical approximations of the twodimensional partial-differential equation describing ground-water flow. A two-dimensional flow problem can be considered based on the following assumptions: (1) the aquifer is confined above and below by layers of material that have much lower conductivity than that of the aquifer; (2) only horizontal flow occurs in the aquifer; and (3) only vertical flow occurs in the confining units in response to pressure changes in the aquifer.

The equation describing two-dimensional ground-water flow in a semiconfined aquifer (Torak, 1992) is

$$
\frac{\partial}{\partial x}\left(K b(h) \frac{\partial h}{\partial x}\right)+\frac{\partial}{\partial y}\left(K b(h) \frac{\partial h}{\partial y}\right)+R(H-h)+W+P=S \frac{\partial h}{\partial t},
$$

where

$x, y \quad$ are Cartesian coordinate directions (length):

$K \quad$ is horizontal hydraulic conductivity (length/time);

$b(h)$ is thickness of the zone between the water table and the bedrock surface (length);

$h \quad$ is hydraulic head in the aquifer (length);

$R \quad$ is vertical hydraulic conductance (vertical hydraulic conductivity divided by thickness) of a confining unit (lime $\mathrm{e}^{-1}$ );

$H \quad$ is hydraulic head in the underlying source bed (length);

$W \quad$ is unit areal recharge or discharge rate (length/time);

$S \quad$ is storage coefficient of the aquifer (dimensionless);

$P \quad$ is $\sum_{j=1}^{p} \delta\left(x-a_{j}\right) \delta\left(y-b_{j}\right) Q_{j}$, the Dirac delta designation for $p$ point sources or sinks, each of strength $Q_{j}$ (length/time) and located at $a_{j}, b_{j}, Q_{j}$ is positive for injection;

$t \quad$ is time. 
In the equation, transient ground-water flow is numerically approximated by using a Galerkin finiteclement procedure to solve the nonlinear partial-differential-flow equation. Details of the methods used for the numerical approximation of the flow equation are given in the documentation of the computer code MODular Finite-Element model (MODFE) (Torak, 1992, 1993a, and 1993b; Cooley, 1992).

\section{Model Design and Time Steps}

To simulate ground-water flow in the alluvial aquifer, the flow domain was discretized using a finiteelement mesh (fig. 8). The basic grid was structured by positioning line segments and nodes so that the resulting elements span, as practically as possible, the limits of the alluvial aquifer in Jefferson County. The basic element shape used by MODFE is a three-node (linear) trianglc. To conserve computer storage and data input time, two triangular clements can be entered as one quadrilateral (four-node) element. Then during simulation, MODFE divides the quadrilateral elements into two triangular elements and does the neccssary computations on each triangular part (Torak, 1992).

A mesh-generating program (M.L. Maslia, U.S. Geological Survey, written commun., 1986) was used on the basic grid structure to provide a more detailed arrangement of elements that are oriented with respect to flow boundaries, aquifer geometry, and pumping centers. The resulting finite-element mesh consists of 1,633 nodes and 1,502 elements. The finite-element mesh covered an area of approximately $85 \mathrm{mi}^{2}$. The mesh was finer in downtown Louisville and Rubbertown where hydraulic gradients were stceper and more data were available. It was coarser outside these two areas where hydraulic gradients were less steep and the data were more sparse. Distances between the nodes varied, ranging from less than $400 \mathrm{ft}$ along the valley wall to more than $3,350 \mathrm{ft}$ along the Ohio River. Element areas ranged from approximalely $280,000 \mathrm{ft}^{2}(6.4$ acres $)$ to $4,468,000 \mathrm{ft}^{2}$ (103 acres).

The finite-element mesh used to simulate ground-water flow in the alluvial aquifer was divided into 21 zones (fig. 9), based on the hydraulic conductivitics of the alluvium, distribution of areal recharge that annually reaches the water table, and the conductance values assigned to the bedrock. Values assigned to all the zones were obtained from available field data and from the modcl calibration process. Actual values used in the final calibration process and rationale behind their use are discussed in the following section.

The Ohio River was included in the modeled area and was represented by a strip of the mesh two elements wide (fig. 8). This strip extended along the entire west side of the model study area.

Simulation of transient conditions also requires discretization of the time domain. A Galerkin-in-time procedure was used to approximate the time derivative. Time steps were sclected to accuratcly maintain the flow-mass balance. Small times steps were selected for the beginning of each model year when waterlevel changes were the greatest. Time steps gradually increased in length for the remainder of the year as water-level changes became less; time steps ranged from 0.5 to 100 days.

\section{Boundary Conditions}

Boundary conditions for the modeled area were chosen to simulate natural hydrologic boundaries (fig. 8). There were two types of houndaries used in the model: specified-head (Dirichlet) and headdependent flux (Cauchy).

The general nature of the physical boundary between the Ohio River and the aquifer is shown in figure 2. Because the aquifer material beneath the river is relatively thin, the river was simulated as a fully penetrating stream. However, a finite thickness of aquifer matcrial does occur at the aquifer/river boundary 


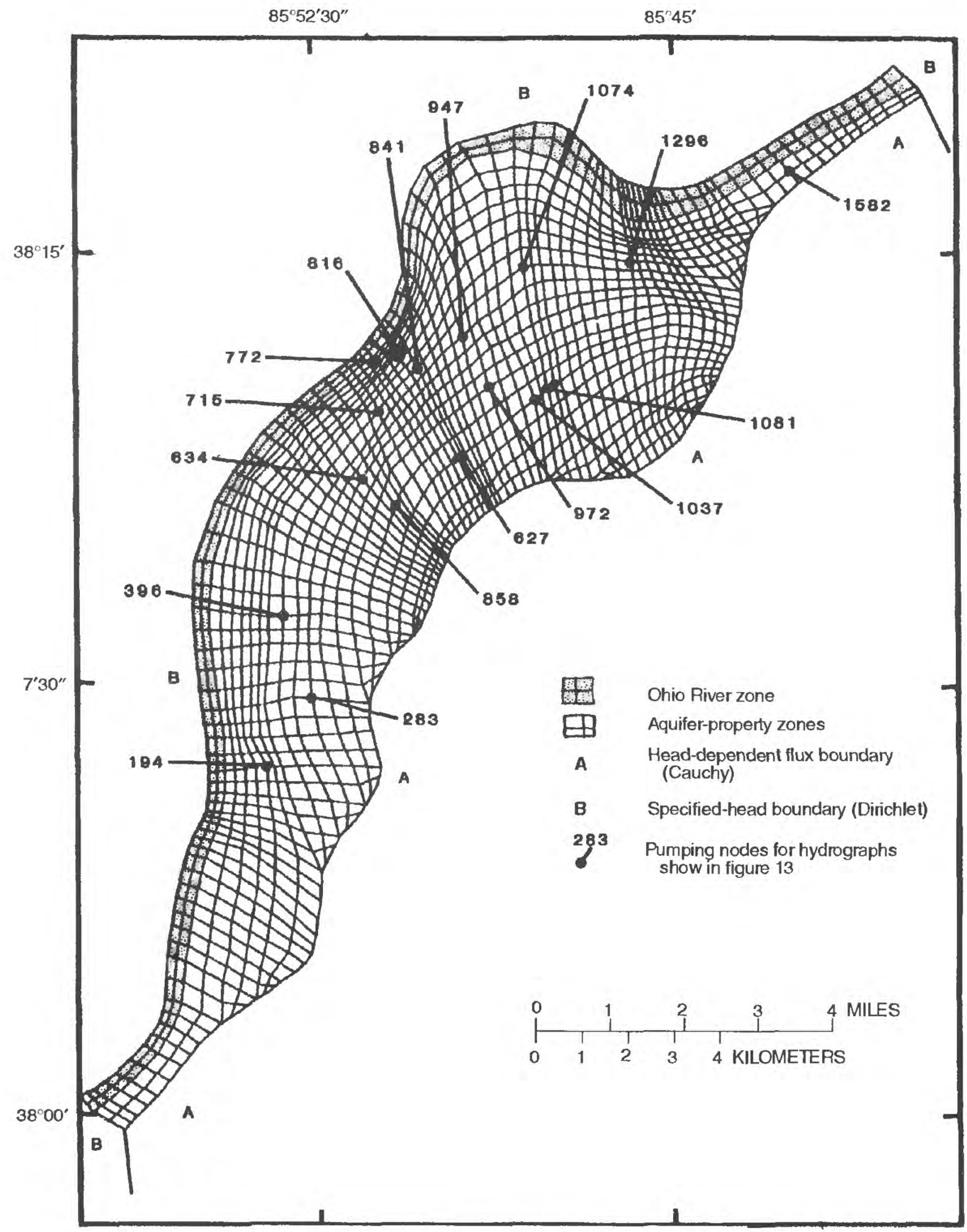

Figure 8. Finite-element grid, aquifer-property zones, and lateral boundary conditions. 


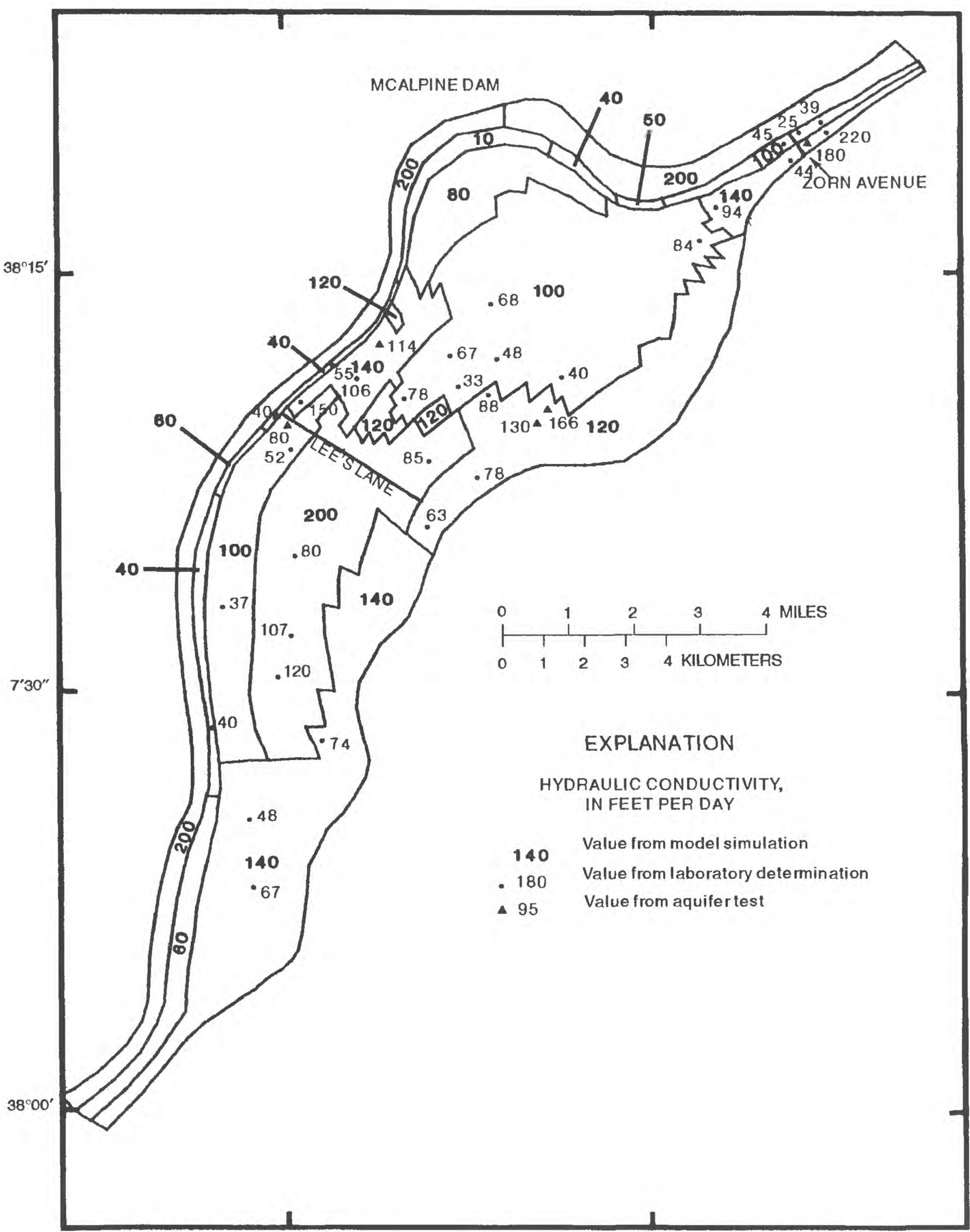

Figure 9. Aquifer-property zones and distribution of laboratory, aquifer-test, and model-simulated hydraulic conductivities.

18 Hydrogeology and Simulation of Ground-Water Flow in the Alluvial Aquifer at Louisville, Kentucky 
and the model boundary was chosen such that head at the aquifer boundary was allowed to fluctuate. Specificd heads were set at nodes located on the far (north) bank of the river. This allowed heads at the aquifer pseudo-boundary (south hank of the river) to fluctuate in response to both river stage and to hydraulic stresses within the aquifer. Specified heads were assigned based on river stages and were updated on a yearly hasis in the transient model.

Specified-head boundaries also were used on the northeastern and southwestern boundaries perpendicular to the river and were based on water-level measurements in nearby alluvial wells. These boundaries were heyond the areas that could influence wilhdrawals in simulations of this study. Specifiedhead boundaries also were used to represent the upper and lower river pools on the upstrean and downstream sides of the McAlpine lock-and-dam system.

Head-dependent flux boundaries were used along the valley wall to simulate flow into the alluvial aquifer from the bordering limestones and shales. Discharge across this boundary was controlled by heads external to the model areas. The boundary coefficients, defined as the transmissivity of the aquifer outside the modeled area divided by the distance from the external head to the boundary of the model, were determined through the calibration process. Boundary coefficients ranged from 0.001 to $2.8 \mathrm{ft} / \mathrm{d}$ and were higher in limestone areas than in shale areas.

Water levels for the external-head nodes used in the model were based on water levels in a few bedrock wells outside the model area and on extrapolation of water levels in the alluvium and the hedrock. The external heads were selected at distance from the aquifer boundary such that they would not be changed by stresses within the aquifer. These head values were updated every 3 to 4 years for the transient simulation based on observed water levels during 1963-83 in wells in the alluvium near the eastern houndary.

The contact between bedrock and the alluvial aquifer was simulated using the vertical hydraulic conductance, which is the vertical hydraulic conductivity of the bedrock divided by its thickness; however, the hydraulic properties of the bedrock were not quantificd in any previous study. Therefore, values used in the model were adjusted through calibration procedures.

\section{Hydraulic Characteristics}

Horizontal hydraulic conductivitics - a measure of the aquifer's ability to transmit water--were estimated using published data from previous aquifer tests and laboratory permeability tests. Direct values for conductivities were obtained from aquifer tests. Laboratory tests of geologic samples provided hydraulic conductivities at 5 -ft intervals below the water table (Rorabaugh, 1946b, p. 16). A median conductivity value for these units was later compiled by Price (1964b). The values for conductivity reported by Rorabaugh and Price were not comparable in accuracy to those obtained on undisturbed material in the field, but were accuratc enough to make comparisons between locations and are shown on figure 9 along with hydraulic conductivities used in the final model calibration. Estimates of median horizontal hydraulic conductivities, based on approximately 40 permeability tests run on geologic samples (Rorabaugh, 1946a), ranged from 25 to $220 \mathrm{ft} / \mathrm{d}$. Fence diagrams that encompass most of the study area also were drawn hy Price (1964a and 1964b) and were based on these and many other geologic borings. Aquifer tesis provided a means for obtaining other estimates of hydraulic conductivity. Values from four tests ranged from 40 to 190 ft/d (Price, 1964b). The distribution of these aquifer test values are also shown on figure 9 for comparison purposes with final calibrated hydraulic conductivities. 
In addition to laboratory analyses of core samples and aquifer tests, additional investigations made in the 1940's (Rorabaugh, 1948, 1949) indicated that horizontal hydraulic conductivity varies in the relatively thin band of aquifer that runs parallel to the Ohio River. Along this path, the aquiler is confined between the bedrock and varying amounts of clay and fine sand. This fine-grained matcrial creates a partial obstruction to the flow of ground water between the aquifer and the river. The most effective connection is along the reach northeast of Zorn Avenue. The hydraulic connection between the river and ayuifer hecomes less effective downstream, especially between McAlpine Dam and Lce's Lane.

Rorabaugh (1946b, p. 36) indicated how permeability can vary along this narrow part of the aquifer hy calculating transmissivity values for an area ncar Lee's Lane (fig. 9). A hydraulic conductivity value of $40 \mathrm{ft} / \mathrm{d}$ was computed from Rorabaugh's transmissivity data for a section of the aquifer near the river's edge. In contrast, a hydraulic conductivity value of $80 \mathrm{ft} / \mathrm{d}$ was obtained for a section of aquifer landward from river's edge near this same sitc. Rorabaugh also ohserved the hydraulic connection of the Ohio River and adjacent aquifer connection by comparing flood effects on the water table at various locations. Rorabaugh's estimate of this hydraulic connection between the aquifer and river was used as a basis for assigning hydraulic conductivity values to the aquifer zones that border the Ohio River. Thus, the highest hydraulic conductivity values were assigned to aquifer zones near the Zom Avenuc area. and the lowest were assigned to zones near McAlpine Dam (fig. 9). The initial estimates were adjusted slightly in modcl calibration.

Areas underlain by limestone (Rorabaugh and others, 1953) have been reported to be more permeable than areas underlain by shale and were assigned larger vertical hydraulic conductivities. Final values used in the model were $1 \times 10^{-3} \mathrm{ft} / \mathrm{d}$ for the limestone bedrock and $2 \times 10^{-5} \mathrm{ft} / \mathrm{d}$ for the slale hedrock. The source-bed heads in the bedrock were estimated for the steady-state models by adding 2 fit to the initial heads in the aquifer, based on a general relation noted on hydrographs (Whitesides and others, 1983).

\section{Model Calibration}

\section{Steady-State Simulation}

The steady-state model of the alluvial aquifer beneath Louisville is intended to represent a period during which the ground-water system was in equilibrium. The rate of recharge to the system, therefore, is equal to the rate of discharge from the system. True stcady-state conditions do not exist for the aquifer system because of variations in ground-water withdrawals and recharge on a small time scale. However, historical water-level trends indicate that the alluvial aquifer was generally at equilibrium conditions occurred during November 1962 and November 1983 (fig. 7h and section on Water Use and Water-Level Fluctuation). For the purposes of this study, it was assumed that the aquifer was at a steady state during these periods.

A calibrated steady-state model should be able to reproduce ohservel water levels for any year the aquifer has reached steady state, given proper values for boundary conditions such as ground-waterwithdrawal rate, recharge, and river stagc. Or the two steady-state periods discussed, the November 1983 period provided the more ideal set of data on which to calibrate the model for two reasons. One reason was that the 1983 data set included areas of the aquifer for which there were no data in the 1962 data set. The other reason was that ground-water withdrawals were much lower in 1983, thus minimizing crrors from uncertainty in withdrawal rates. Although the 1983 data set was more complete, a 1962 stealy-state model 
was needed to generate initial heads for a transient simulation, so the model was calibrated primarily to the 1983 data set while maintaining an acceptable match to the 1962 data set, given appropriate changes in boundary paramelers. This is discussed further in the section on Sensitivity Analysis.

\section{Data Input}

Steady-state simulations were made using the distribution of hydraulic conductivities within the aquifer discussed earlier (fig. 9), vertical hydraulic conductance of the limestone and shale bedrock (fig. 10), and the distribution of areal recharge (fig. 11). Minor adjustments were made to the size and shape of the aquifer zones during the model calibration. Adjustments were made within the limits of the data as discussed in the Hydraulic Characteristics Section. Arcal recharge rates were the average annual rate for each aquifer 7 one.

The areal recharge rates of 0,2 , and 6 in. represent the average annual recharge to the water table for 1983. No recharge to the water table was entered for the river zones and for the zone that encompasses most of Louisville's business and industrial districts (figs. 1 and 11). Virtually all of the business district contains buildings and paved areas. Precipitation generally is routed from the paved areas toward drains and then into sewers. Standing water is typically lost to evapotranspiration. Areas receiving only $2 \mathrm{in} / \mathrm{yr}$ of recharge to the water table coincide with "fringe" areas. These areas contain some business, industry, and residential dwellings, but limited infiltration occurs. The $6 \mathrm{in} / \mathrm{yr}$ infiltration rate provided an acceptable water-level match in rural areas. Selection of this amount of recharge is described in more detail in the section "Natural Recharge" and is hased primarily on previous investigations. Recharge for 1962 was based on the ratio of the above infiltration to the total precipilation for 1983 times the total precipitation for 1962.

Model values for the Ohio River stage were obtained from water-surface altitudes for November 1962 and November 1983. The stage used for the steady-state simulation above the lock-and-dam system remained constant at $420 \mathrm{ft}$. Below the lock and dam, river stage was 390.2 and $383 \mathrm{ft}$ in 1962 and 1983 , respectively. These stages correspond to a river discharge of about $170,000 \mathrm{ft}^{3} / \mathrm{s}$ and approximate the flow conditions that typically occur in late November.

The ground-water-withdrawal rate used in the model for November 1983 was $1.34 \mathrm{Mft}^{3} / \mathrm{d}$; however, actual pumpage from the alluvial aquifer was unknown. Pumping nodes used in the model are shown in figure 8. Withdrawal rates were estimated from the permitled rates recorded at the Kentucky Natural

Resources and Environmental Protection Cabinet. Ground-water users extracting more than $1,337 \mathrm{ft}^{3} / \mathrm{d}_{\text {are }}$ required to obtain penmits and report any changes to the State agency. Reported witldrawal rates may have bcen based on pump design or requested permit rates rather than on actual rates; therefore, it was reasonable to adjust rates from the reported rates.

\section{Results of Steady-State Calibration}

A comparison of simulated heads with the corresponding observed heads provided an indication of how well the model simulated the hydrologic system (figs. 12a and 12b). In November 1962, simulated and ohserved water levels differed by less than $5 \mathrm{ft}$ in 64 percent of the wells and by less than $10 \mathrm{ft}$ in 88 percent of the wells. In Novemher 1983, simulated and ohserved heads differed by less than 5 ft in 76 percent of the wells and by less than 10 ft in 97 percent of the wells. 


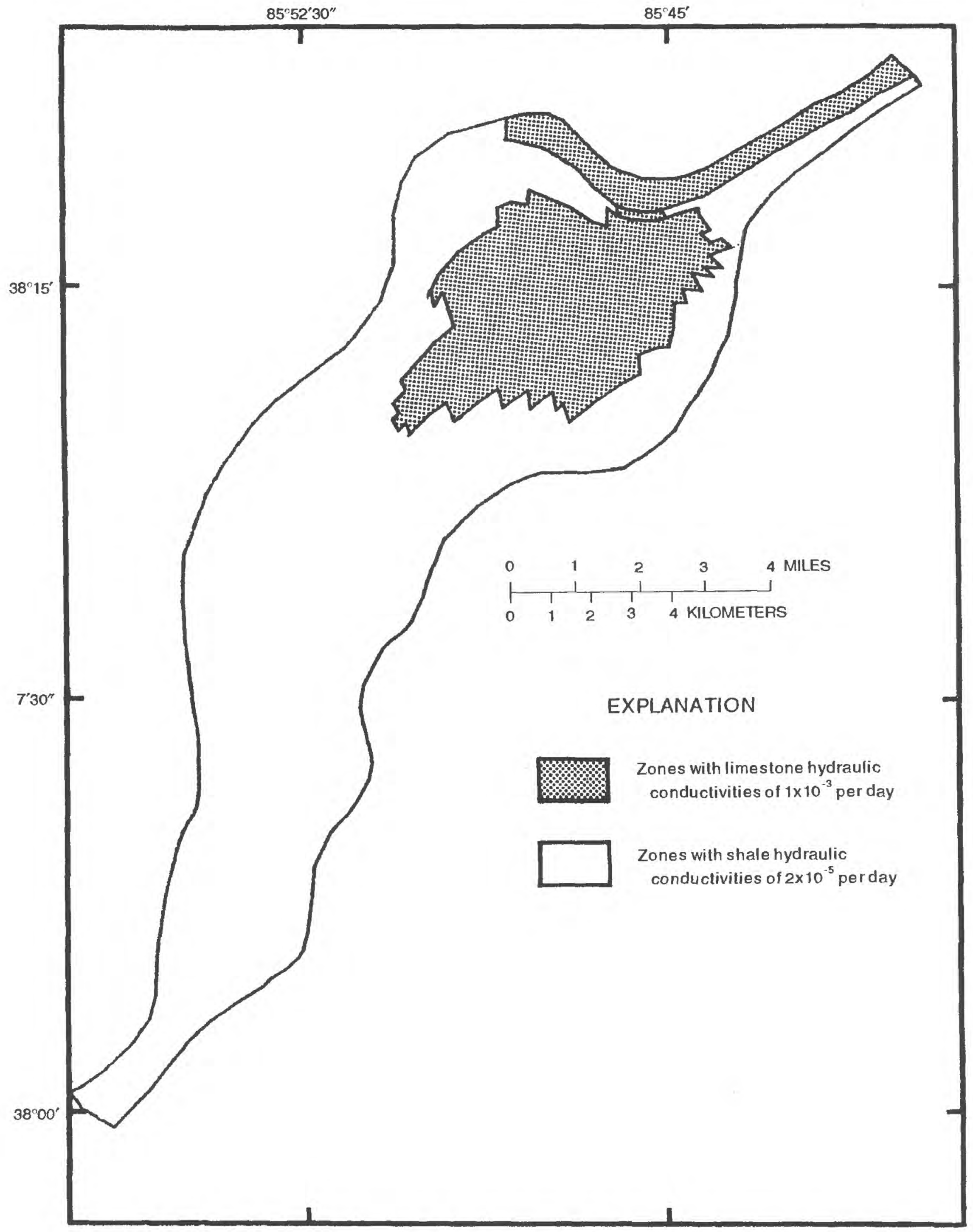

Figure 10. Distribution of model-simulated hydraulic conductivities of the limestone and shale bedrock. 


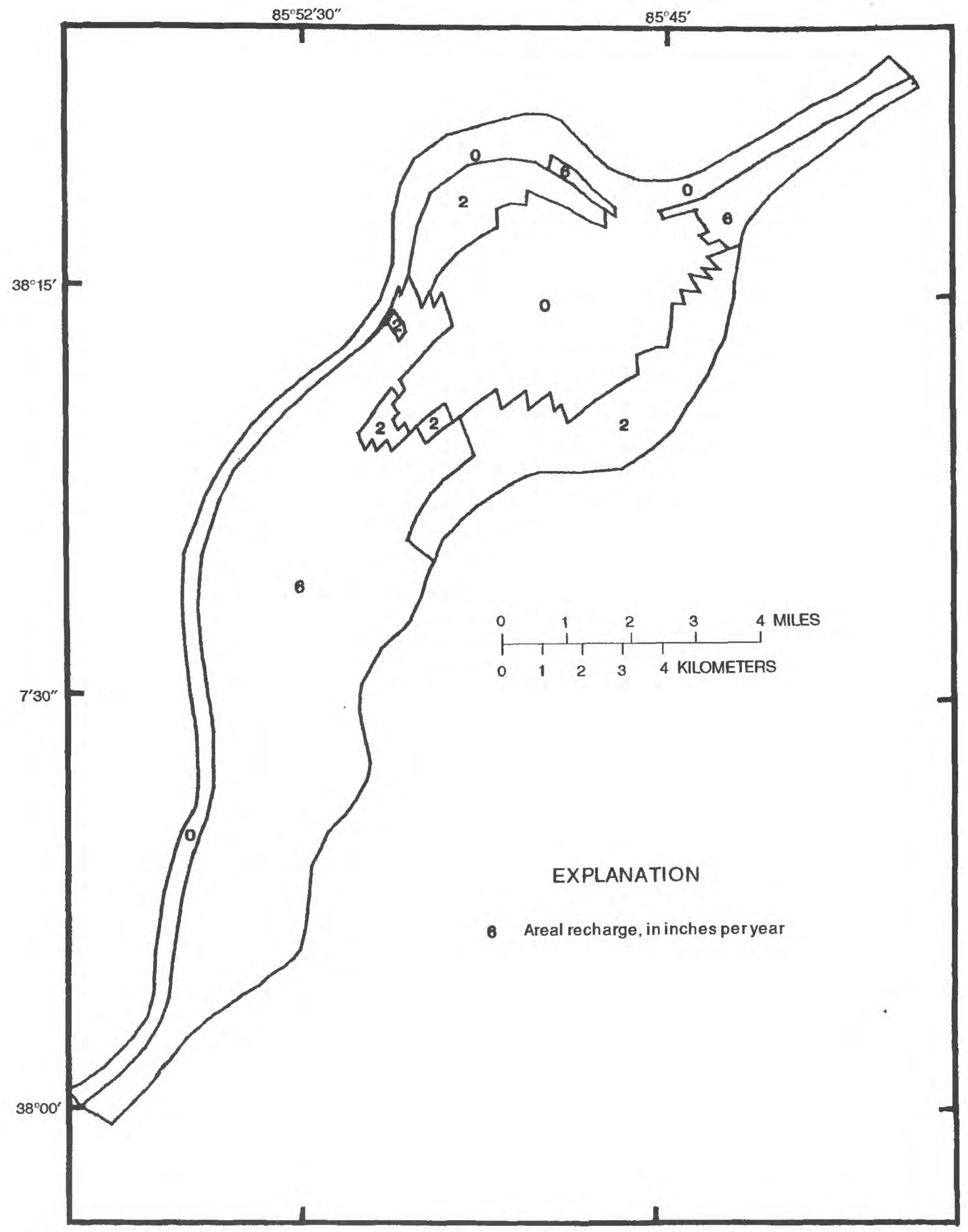

Figure 11. Distribution of areal recharge that reaches the water table annually. 


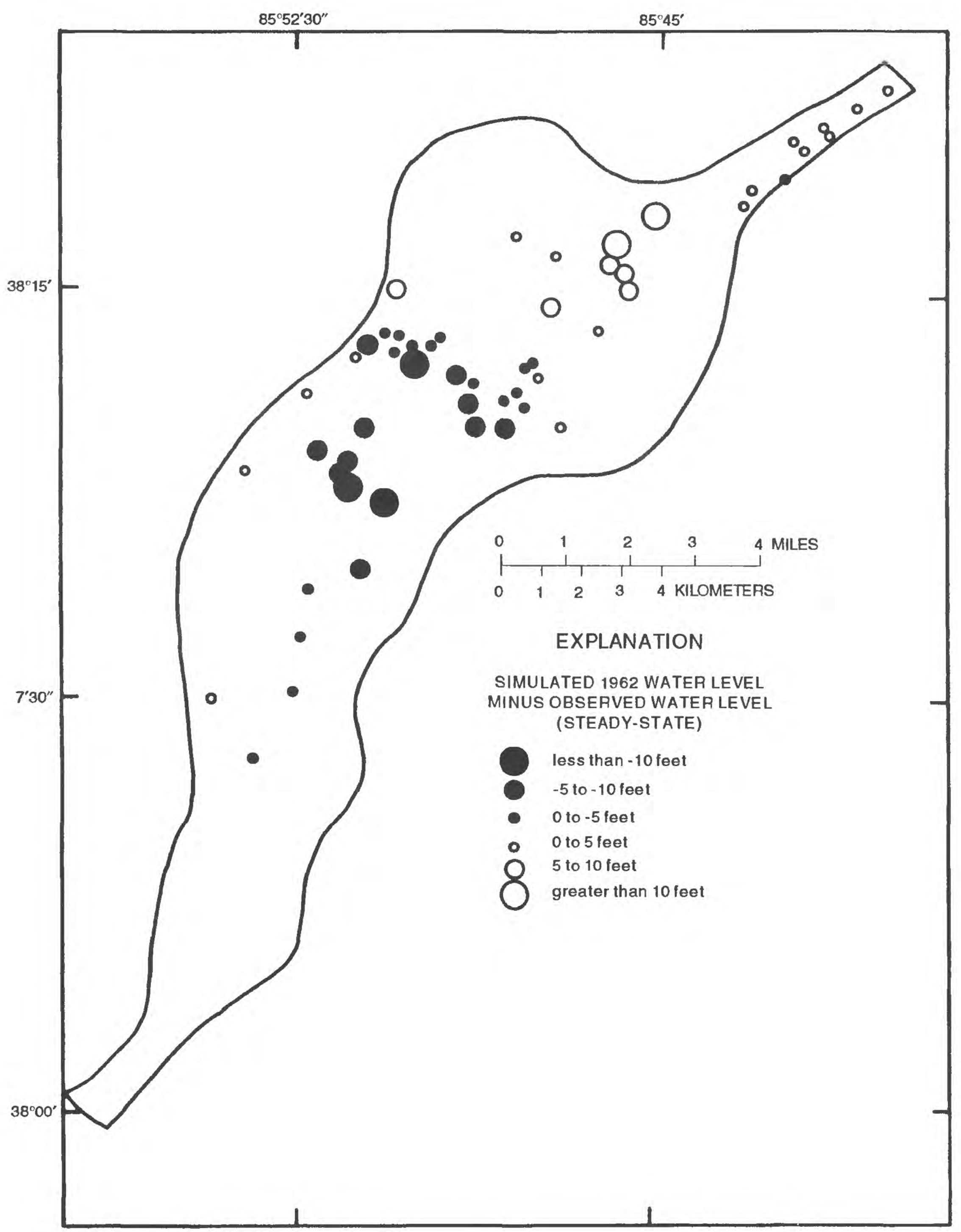

Figure 12a. Comparison of measured water levels and simulated water levels, November 1962. 


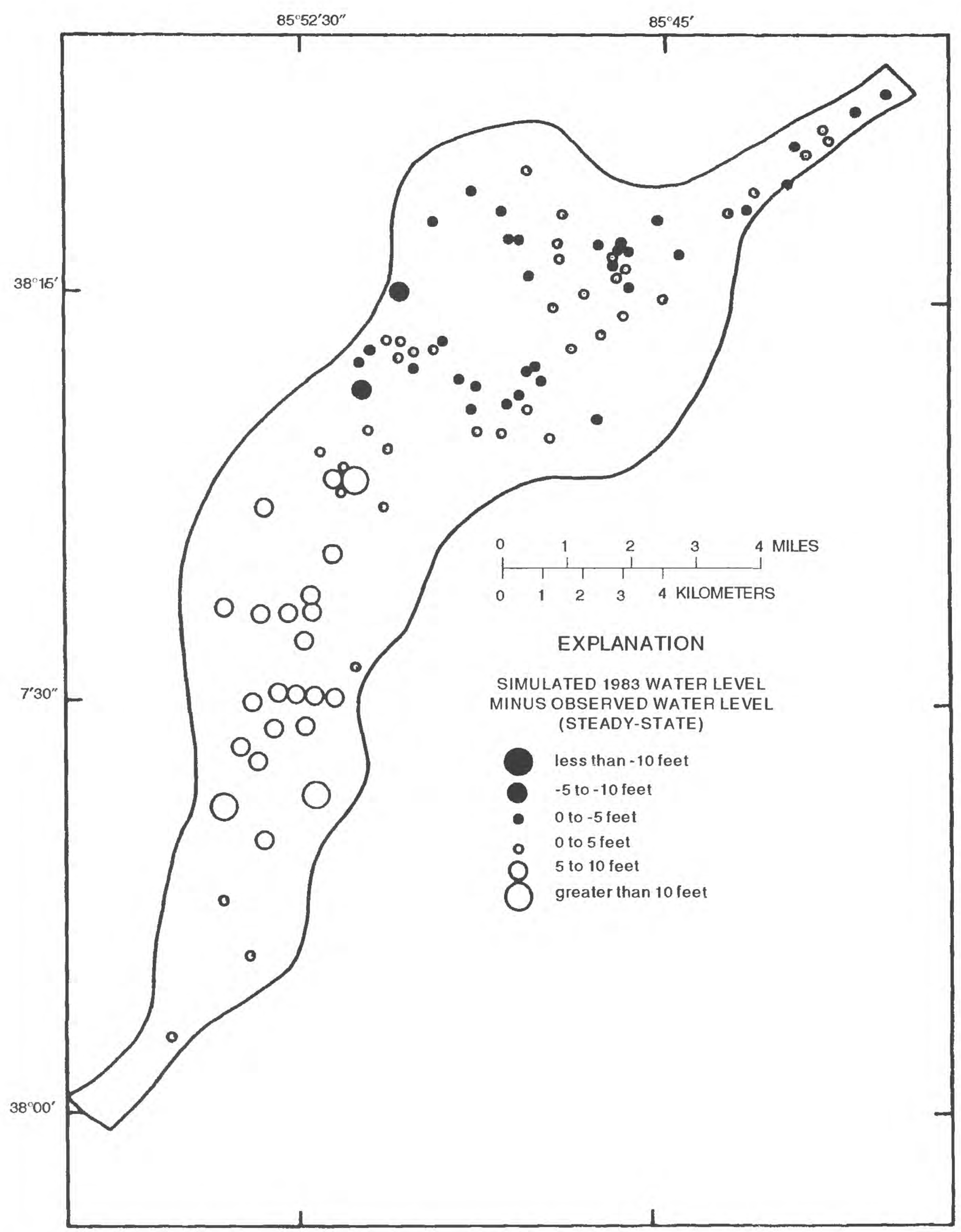

Figure 12b. Comparison of measured water levels and simulated water levels, November 1983. 
When plotted on a map, the model residuals - the differences between computed and observed water levels-were not random; certain areas had systematically positive or negative residuals. This spatial bias in the model indicated that some aspect of the model could have been specified differemtly or in more detail to eliminate the bias. If the bias were the same in the simulation of 1962 conditions as in the simulation for 1983 conditions, the model could simply he adjusted to eliminate the bias; however, the bias was not the same in both simulations. The break on the map between groups of positive and negative residuals occurred at the geologic contact between the shale and the limestone underlying the aquifer. The bias probably was related to the specification of the boundary condition at the base of the aquifer, which required an estimation of heads in the shale or limestone bedrock (extemal heads). The vertical hydraulic gradient at one observation point was used uniformly throughout the model regardless of bedrock lithology. As stresses were applied to the aquifer, the vertical hydraulic gradient prohably was different in areas underlain by shale and by limestone. The model presented in this report was calibrated using boundary conditions that probably occurred between the high ground-water-withdrawal period around 1962 and the low withdrawal period around 1983 and generally represents an average condition. A more exact definition of the external heads was not possible with the available data.

In addition to simulated heads, the calibrated steady-state model provided a simulated ground-water budget for the aquifer (table 2). The 1983 simulation indicated that, of the total recharge to the alluvial aquifer, rainfall provided approximately 42.6 percent, flow from the Ohio River to the aquifer (induced by pumped wells near the river) provided about 17.8 percent, flow across the valley wall houndary provided about 18.2 percent, sewage effluent recharge provided about 5.8 percent, and flow through the limestone upward to the alluvium provided approximately 15.6 percent. Flow from the aquifer to the Ohio River accounted for approximately 67.3 percent of the discharge and ground-water withdrawals for 32.7 percent in 1983.

\section{Effect of Dam on Simulated Flow Values}

The McAlpine lock-and-dam system near downtown Louisville forms an upper and lower pool on the Ohio River (fig. 1). River stage of the upper pool is generally maintained at $420 \mathrm{ft}$ above sea level by manipulating tainter gates at the dam. River stage of the lower pool generally ranges from 383 to $420 \mathrm{ft}$ above sea level and primarily depends on operations of the downstream Cannelton lock-and-dam system. These operations can result in a 37-ft lowering of the water-surface altitude at the McAlpine Dam during periods of low water.

Large artificial fluxes were computed by the model because of the gradients created between upper and lower river pools and because of the discretization of the model grid. Typically, the simulated fluxes balanced each other within a few percent as flow left the system as a result of the hydraulic gradient between upper and lower pools or entered the system in order to maintain specified heads at the upper pool stage. Because the simulated fluxes are a numerical consequence of a coarse discretization in the area of the dam, they do not accurately represent localized ground-water flow through the aquifer. The effect of these fluxes on the mass balance in the model, therefore, has been ignored. 
Table 2. Simulated components of the ground-water budget for the alluvial aquifer under steady-state conditions, 1962 and 1983

[MCFD, million cubic feet per day; - . not available]

\begin{tabular}{|c|c|c|c|c|c|}
\hline & \multicolumn{2}{|c|}{1962 Water budget } & \multicolumn{2}{|c|}{1983 Water budget } & \multirow{2}{*}{$\begin{array}{l}\text { Ratio of change in } \\
1962 \text { and } 1983 \text { water } \\
\text { budget, in MCFD }\end{array}$} \\
\hline & MCFD & Percent & MCFD & Percent & \\
\hline \multicolumn{6}{|l|}{$\underline{\text { Recharge }}$} \\
\hline Rainfall & 1.47 & 28.3 & 1.75 & 42.6 & 0.84 \\
\hline Leakage & .77 & 14.8 & .64 & 15.6 & 1.20 \\
\hline $\begin{array}{l}\text { Flow from } \\
\text { valley wall }\end{array}$ & 1.02 & 19.7 & .75 & 18.2 & 1.36 \\
\hline Ohio River & 1.93 & 37.2 & .73 & 17.8 & 2.64 \\
\hline $\begin{array}{l}\text { Sewer } \\
\text { effluent }\end{array}$ & - & - & .24 & 5.8 & 一 \\
\hline Total & 5.19 & 100 & 4.11 & 100 & 1.26 \\
\hline \multicolumn{6}{|l|}{ Discharge } \\
\hline Withdrawal & 3.57 & 68.9 & 1.34 & 32.7 & 2.66 \\
\hline River & 1.61 & 31.1 & 2.76 & 67.3 & .58 \\
\hline Total & 5.18 & 100 & 4.10 & 100 & 1.26 \\
\hline
\end{tabular}

\section{Transient Simulation}

\section{Calibration Procedures}

Transient simulations were done using well hydrographs as an adlditional calibration aid to test the appropriateness of the houndary conditions and to estimate the aquifer storage coefficient. Well hydrographs document a transient response of the aquifer (rising water levels) to an imposed stress (decrease in withdrawal rates). The model should accurately simulatc this response if (1) the steady-state model is accurate, (2) the method of estimating time-dependent conditions at the boundaries works is correct, and (3) estimates of the storage coefficient are accurate. The storage coefficicnt, which allows a time-variant response of heads to stress, was the only parameter necded to do the simulation.

Changes in water levels were simulated for the transient period November 1962 to November 1983. Initial heads were selected from 1962 conditions because stresses due to pumping were relatively constant in 1962 and water levels throughout the aquifer were relatively stable (Bell, 1966). The iritial values of hydraulic head were calculated in the 1962 steady-state model. These heads were the result of a calibrated steady-state model and, therefore, caused minimal fluctuations at the start of the transient simulation. In 
the transient model, source-bed (bedrock) heads were adjusted in the model code by adding $2 \mathrm{ft}$ to the aquifer head at the end of each time-step; thus, the lower boundary of the aquifer was simulated essentially as a specified flux.

Model output consisted of changes in hydraulic head with respect to time and a yearly water budget tahulation for the period 1962-83. This transient period included a wide range of ground-water-withdrawal rates from the aquifer (fig. 6c). Some withdrawal rates used in the final model differed from actual reported rates. Differences in permitted or reported withdrawal rates and those used in the model were considered justified for the following reasons:

1. Records of ground-water withdrawal before permit requirements (1967) were questionable and were dependent on answers supplied by users during telephone surveys.

2. Reported rates may have been based on anticipated rates and not actual rates.

3. Withdrawal rates less than $1,337 \mathrm{ft}^{3} / \mathrm{d}$ were not required to obtain permits for ground-water withdrawal.

Adjustments were within 20 percent of reported values, and where differences occurred, changes made to the values were primarily based on an attempt to match observed water-level conditions by adding or subtracting a reasonable value of pumpage to the reported value.

Most other aquifer stresses, such as recharge from rainfall and the river, were updated annually for the transient simulation. Septic-tank inflow was added to the system each year from 1970 to 1983. The areas recciving septic-tank inflow were relatively undeveloped prior to 1970.

Areal recharge from precipitation was changed each year and was calculated as a percentage of total precipitation received in the Louisville area. The percentage used was based on the 12-percent-average infiltration of precipitation that Rorabaugh (1946b) estimated for rural areas, 4 percent of total precipitation received in suburban/commercial areas, and zero percent infiltration in heavily paved and industrialized downtown areas. Of the total study area, approximately 60 percent was considered rural, 20 percent was considered suburban/commercial, and 20 percent was heavily paved downtown area.

The specified-head nodes along the Ohio River were specified as the average river stage for the month of November for each year. The average annual stage in the river is close to the normal pool elevation; however, water levels in wells near the river respond quickly to river-stage fluctuation (figs. 6a and 7a), and water levels observed at a point in time may be influenced by temporary high stages in the river. The average river stages for each November were used in the boundary condition to allow general comparison with ground-water levels also measured in November.

\section{Storage Coefficient and Specific Yield}

The ability to store and transmit water are important hydraulic properties of aquifers. The magnitude of water-level change that occurs in an aquifer in response to gaining or losing water is reflected by the storage coefficient. The storage coefficient is defined as the volume of water that an aquifer releases from or takes into storage per-unit surface area of the aquifer per-unit change in head (Heath, 1983). In a confined aquifer, water is released from storage when a drop in pressure causes the slight expansion of the water and a slight compaction of the aquifer. In an unconfined, water-table aquifer, water is released from storage by the draining of pore spaces and a lowering of the water table. The storage coefficient of a water- 
table aquifer is sometimes referred to as specific yicld. The amount of water released from storage in a confined aquiler is small compared to that from a water-table aquifer (Bear, 1979); thus, the specific yield of an unconfined aquifer may be 100 to $10,0(0)$ times the storage coefficient of a confined aquifer.

The transition from a confined to an unconfined aquifer has been observed and documented in at least one aquifer test in the study area (Walker, 1961; and Rorabaugh, 1948, p. 53). Walker computed a value of 0.2 for specific yield near the end of the aquifer test after the transition from confined to unconfined conditions was observed during analytical analyses of the aquifer test results. Rorabaugh (1946b. p. 31) calculated available ground water in the southwestem part of the study area using a specific yicld of 0.2 after obtaining laboratory test results on material from the alluvial aquifer ranging from 0.15 to 0.23 . Also, by analyzing carly results (before recharge from the river occurred) of an aquifer test adjacent to the Ohio River and hefore the Iransition from confined to unconfined conditions occurred, Rorabaugh (1948, p. 53) estimated a storage coefficient of $3 \times 10^{-4}$.

Other authors have presented typical values of specific yield for alluvial sand and gravel aquifers. Barker and others (1983) presented a range of specific yicld from about 0.1 to 0.25 and used a range from 0.14 to 0.20 in their model for an alluvial aquifer in Kansas. Freeze and Cherry (1979) presented a range of specific yield in unconfined aquifers from 0.01 to 0.30 .

The finite-element code used for this study allows a confined-aquifer condition (and corresponding storage coefficient) to convert to an unconfined-aquifer condition if water levels drop below the altitude of the bottom of a confining layer. Under 1983 conditions, only about 8 percent of the nodes were considered to be under confined conditions (water level was above the bottom of the confining clay cap). The model was programmed to use a storage coefficient of $2 \times 10^{-4}$ for these nodes and to adjust to a specific yield value of 0.15 under unconfined (water table) conditions. Unconlined conditions might occur when pumping begins at a node where confined conditions exist. The storage coefficient value of $2 \times 10^{-4}$ for confined conditions was held constant for all simulations. The storage coefficient of the underlying bedrock was not considered in the simulations.

\section{Results of Transient Simulation}

Hydrographs of simulated hydraulic heads and measured water levels at 17 sites for the period 1962-83 are shown in figures 13a-e. The hydrographs represent locations in the study area (fig. 8) that have a range of hydrologic conditions. The sites for which hydrographs are presented include sites near the Ohio River and the eastem valley wall, sites near pumping centers, and sites relatively unaffected by pumping. The simulated water levels represent head at the finite-element nodes nearest the respective wells.

In general, the simulated water levels compare favorably with the measured values for the same period of time. The hydrographs indicate that the transient model reasonably simulated the response of the aquifer to the transient water-level conditions. 

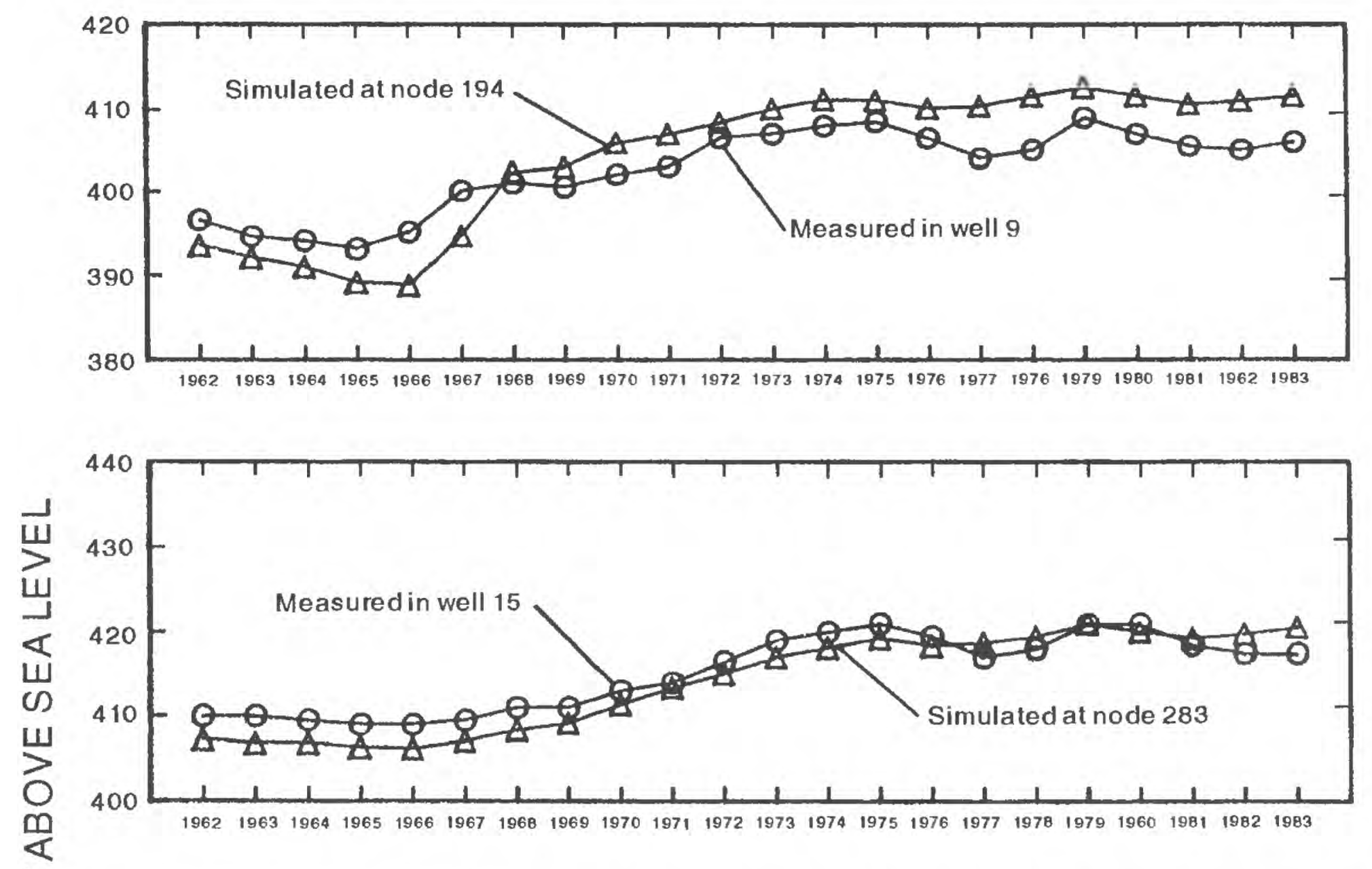

U

山

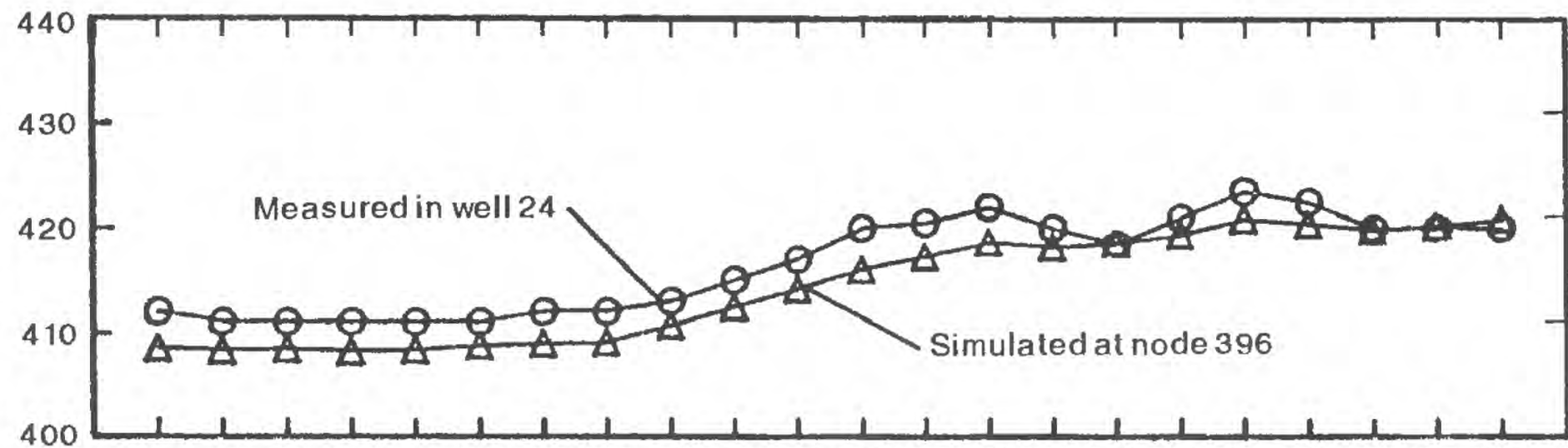

$\begin{array}{lllllllllllllllllllllll}1962 & 1963 & 1964 & 1965 & 1966 & 1967 & 1968 & 1969 & 1970 & 1971 & 1972 & 1973 & 1974 & 1975 & 1976 & 1977 & 1978 & 1979 & 1980 & 1981 & 1982 & 1963\end{array}$

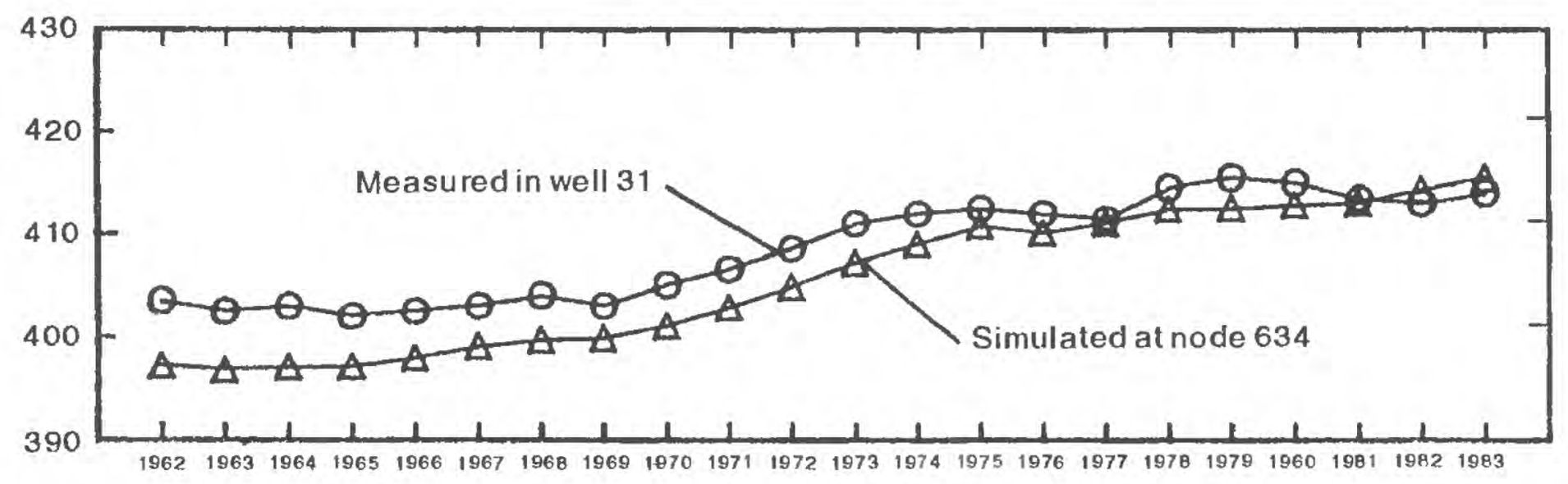

Figure 13a. Measured and simulated water levels at selected sites, 1962-83. (Tick marks on horizontal scale represent measurements and corresponding simulations during the period November 20-25 of the indicated year. See figure 8 for location of nodes.) 



$-$

Ш

世
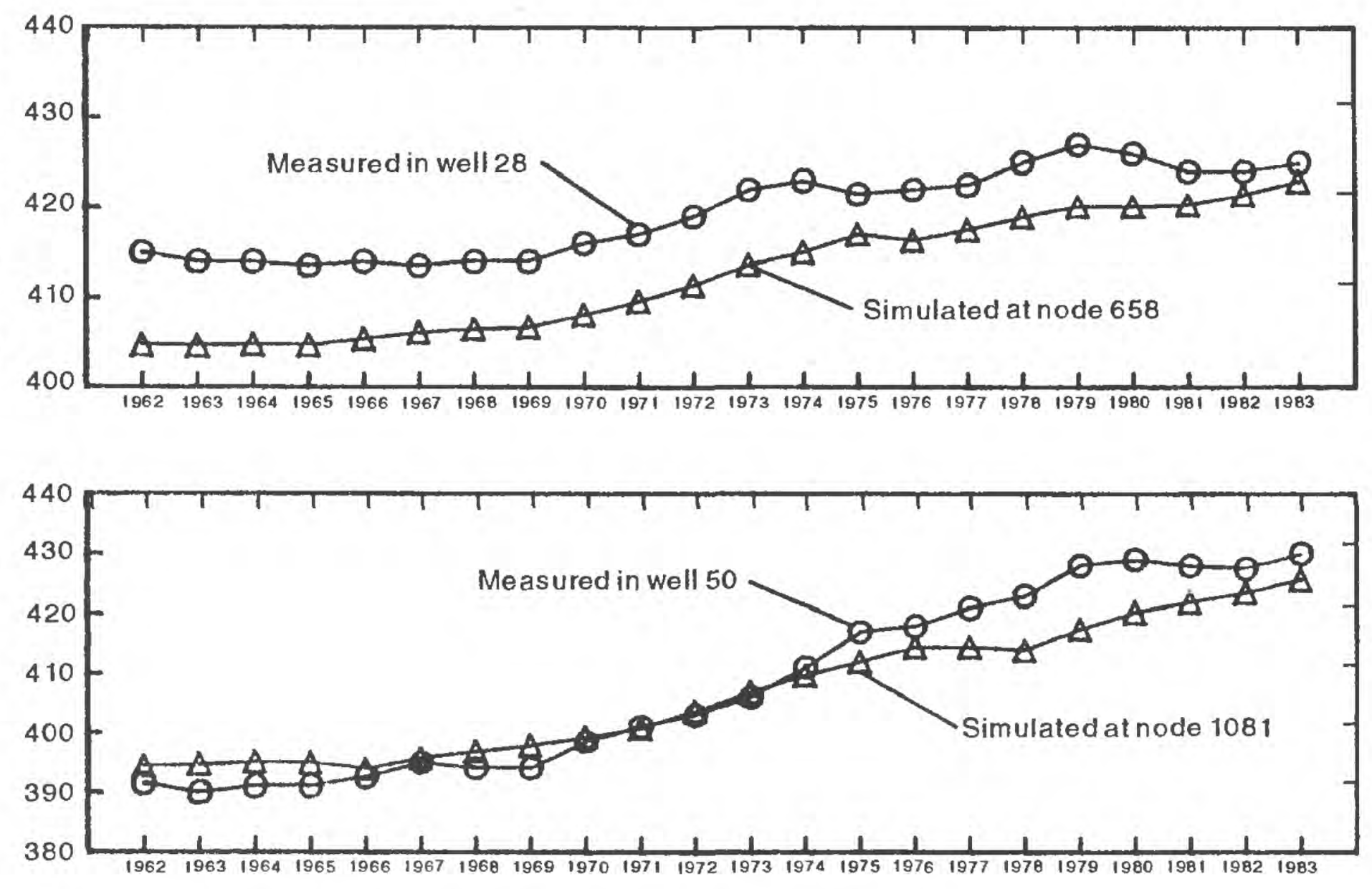

Figure 13b. Measured and simulated water levels at selected sites, 1962-83. 


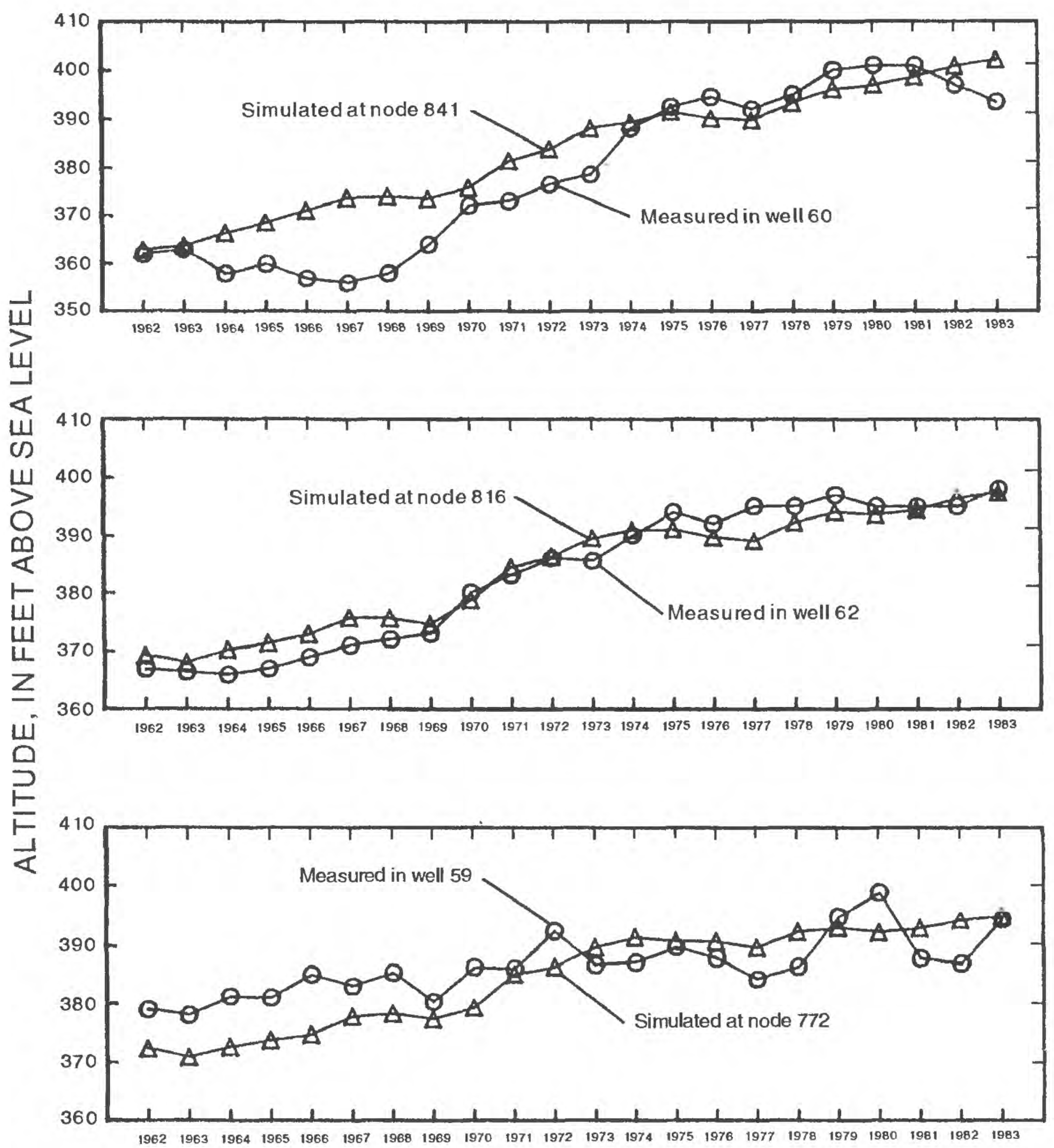

Figure 13c. Measured and simulated water levels at selected sites, 1962-83. 


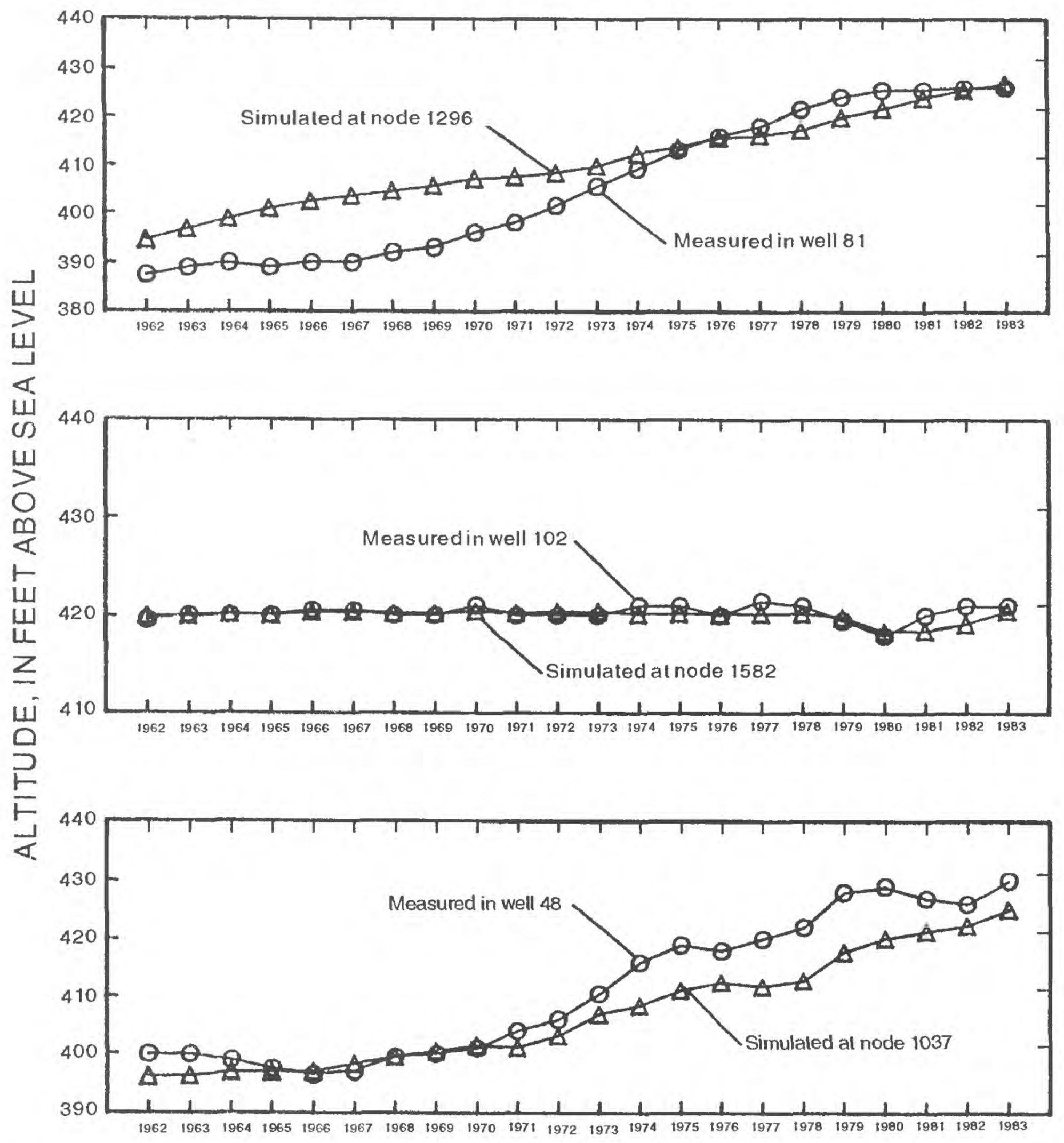

Figure 13d. Measured and simulated water levels at selected sites, 1962-83. 


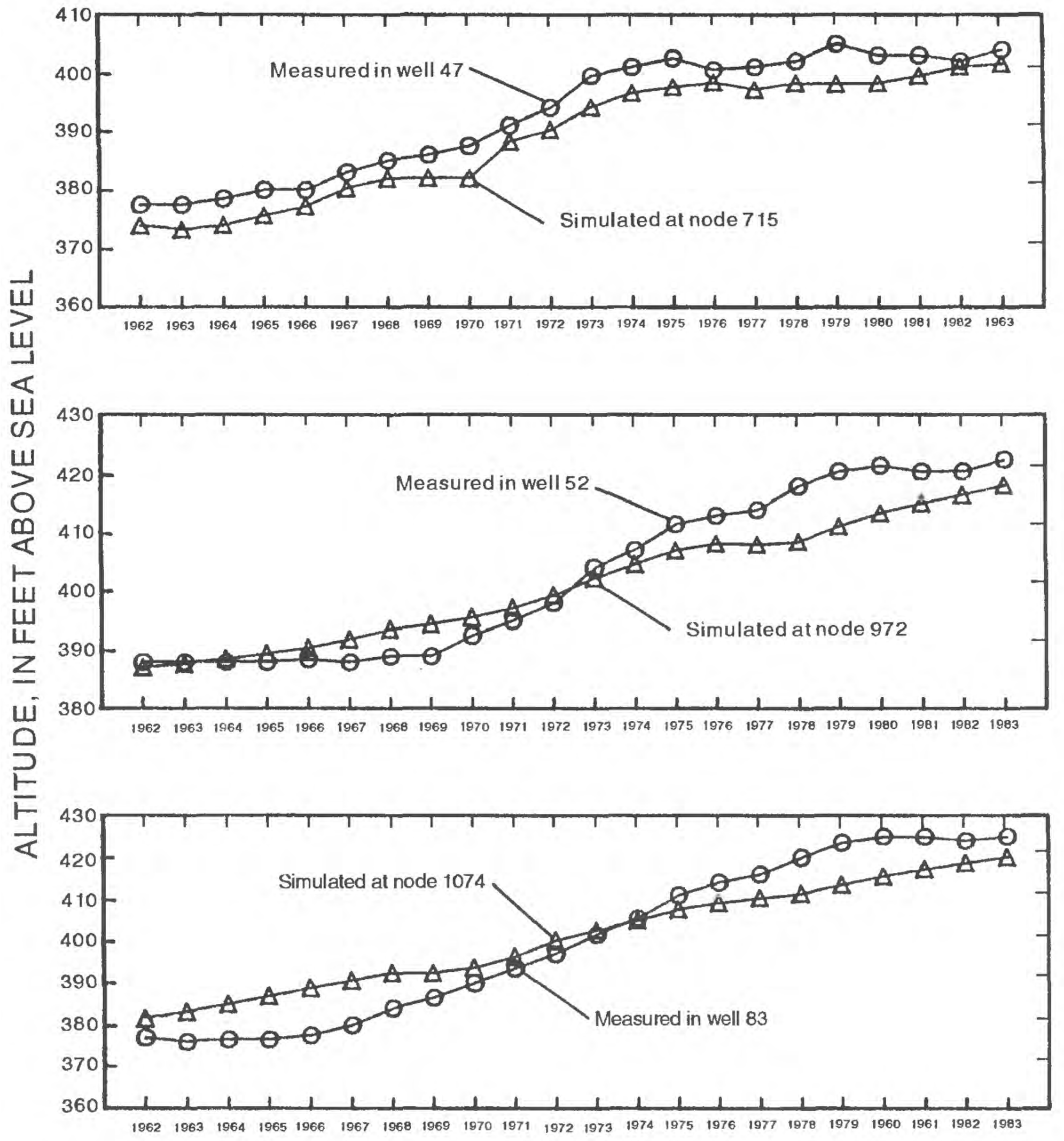

Figure 13e. Measured and simulated water levels at selected sites, 1962-83. 
To compare changes from 1962 to 1983 in water-budget components (table 2) between the steadystate and the transient-state simulations, ratios were constructed for each component by dividing the yearly average flow (million cubic feet per day) rate for 1962 by the yearly average flow rate for 1983 . A ratio greater than 1.00 indicted that a component decreased in value during 1962 and 1983; however, its relative importance to the budget increased. A ratio of 1.00 indicated the relative importance did not change during the period. Table 2 indicates that only rainfall $(0.84)$ and discharge to the river $(0.58)$ increased during 1962-83. The ground-water bulget components of recharge from lcakage (1.20), recharge from flow from valley wall (1.36), recharge from the Ohio River (2.64), and discharge from ground-water withdrawals decreased during the simulation period. The most important changes to be noted are the decrease in ground-water withdrawals and the decrease in recharge from the Ohio River.

The simulated water budget for 198.3 steady-state conditions indicated that precipitation provided 42.6 percent of recharge to the aquifer, flow from the Ohio River provided 17.8 percent. and lateral flow from the eastern valley wall to the alluvium provided 18.2 percent. Upward flow from limestone be(lrock 10 the alluvium and recharge from septic tanks in unsewered areas accounted for the remaining 21.4 percent. Flow from the alluvial aquifer to the Ohio River was 67.3 percent of the total discharge and ground-water withdrawal was 32.7 percent.

\section{Sensitivity Analysis}

A sensitivity analysis was used to determine if the set of calibrated model parameters produced the estimate of heads with the least error when compared with observed heads. To make this determination, each parameter was varied, one at a time, above and below its calibrated values. By running the model with new parameter values, new measures of error were calculated (fig. 14). Idcally, any change in a parameter value should increase the measure of error; however, hecause only one parametcr at a time was varied, the sensitivity analysis did not account for interaction between the parameters. Possible interaction between parameters can lead to the phenomenon that more than one set of parameter values can yicld approximatcly the same root mean square error (RMSE). The alternative - adjusting combinations of parameters - leads to too many possible combinations to be useful; so the single-variable sensitivity analysis was uscd in this study. A standard statistical test, the RMSE, was used in the sensitivity analysis. The equation for RMSE is

$$
\text { RMSE }=\sqrt{\frac{1}{N} \sum_{i=1}^{N}\left(h_{m}-h_{s}\right)^{2}},
$$

where
$N \quad$ is the number of measured water-level measurements $(N=101)$;
$h_{m}$ is the measured water level (length);
$h_{\mathrm{s}} \quad$ is the simulated water level (length).

The RMSE was $5.86 \mathrm{ft}$ in 1962, based on 58 observed water levels, and $4.16 \mathrm{ft}$ in 1983 , based on 101 observed water levels (figs. 12a and 12b). 

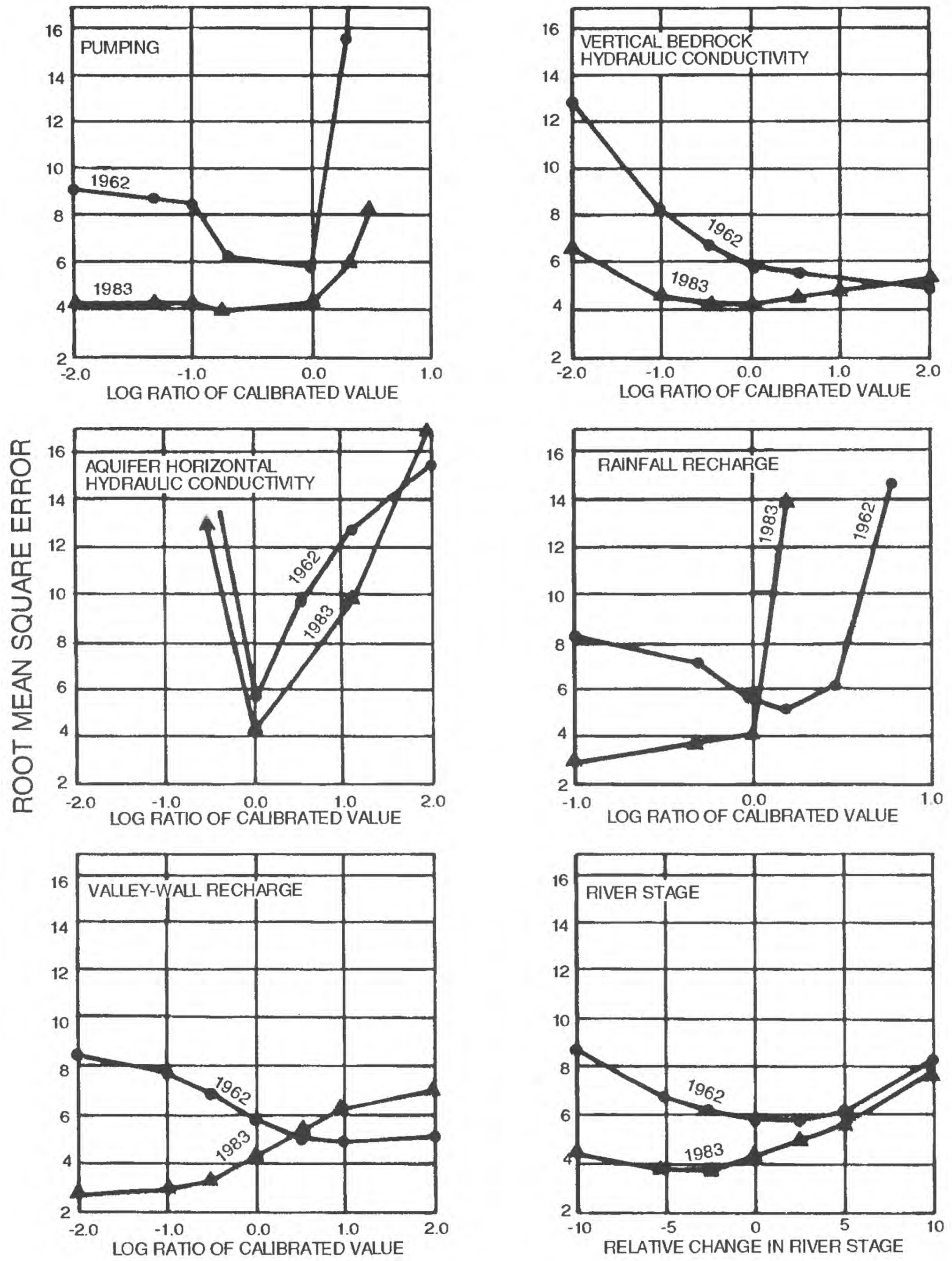

Figure 14. Sensitivity of simulated heads to changes in selected variables used in the model. 
Horizontal hydraulic conductivity of the aquifer, both the horizontal and vertical hydraulic conductivity in bedrock, effective rainfall recharge, the coefficient of the head-dependent boundary at the valley wall, river stage, and pumping were adjusted individually through a range of values in the steadystate model, while all other variables were held constant. The common logarithm of the ratio of the adjusted value to the calibrated value was then plotted against the RMSE.

In the calibration of the steady-state model, the error in both the 1962 and the 1983 data sets were considered and an attempt made to minimize the error for both years simultaneously; however, more weight was given to the 1983 calibration because of the larger and more complete data set. Ideally, the graplss (fig. 14) slould rise from the logarithm of the ratio plotted at 0.0 (the logarithm of 1 , representing the value used in the model) for both increasing and decreasing values of the parameter. Based on this criterion, the model indicated the greatest sensitivity to horizontal hydraulic conductivity. The model was less sensitive to other parameters. The sensitivity analysis indicated that the withdrawal rates used in the models were probably maximums because increases in rate led to large increases in error. The flat parl of the sensitivity curve for pumping (fig. 14) can be explained as follows. As the pumping rate at a well decreases, the size of the cone of depression decreases. Eventually, it becomes small enough that it does not include any observation wells, so any further reduction in pumping rate does not change the RMSE.

The aquifer zone representing the Ohio River was assigned a hydraulic conductivity higher than any other zone $(200 \mathrm{ft} / \mathrm{d})$. A test was made of the effect of choosing this value by assigning higher values $(400$ and $600 \mathrm{ft} / \mathrm{d})$. Several trial model runs showed that these higher values of hydraulic conductivity had no affect on computed heads.

Both the vertical hydraulic conductance of the bodrock and the coefficient of the head-dependent boundary at the valley wall controlled flow from outside the alluvium. Most flow from outside was from solution channels and (or) fractures in the limestone that are not evenly distributed throughout the area, but are concentrated in certain areas (Rorabaugh, 1948, p. 40; and Rorabaugh, 1949, p. 20-21). The model treated these solution channels and (or) fractures as being areally distributed; however, there may be greater error associatcd with model-computed heads in areas of the alluvial aquifer that overlay these features.

A sensitivity analysis was also done on computed hydraulic heads by uniformly changing the specific yield for the transient simulation (fig. 15). The sensitivity analysis did not include varying the storage coefficient because the aquifer was unconfined over most of its extent. The procedure was the same as that followed in the sensitivity analysis of the steady-state model. Three specific yield values were used: (1) the calibrated value $(0.15)$; (2) half the calibrated value (0.075); and (3) twice the calibrated value (0.30). All three produced approximately the same RMSE over the transient period. Of the three tests of sensitivity, the lowest specific yicld resulted in the highest RMSE for the first half of the transient period and the lowest RMSE for the second half. The highest specific yield had the opposite effect. The specific yield used in the calibrated model resulted in a more consistent RMSE, representing all years better than the other two specific yields. 


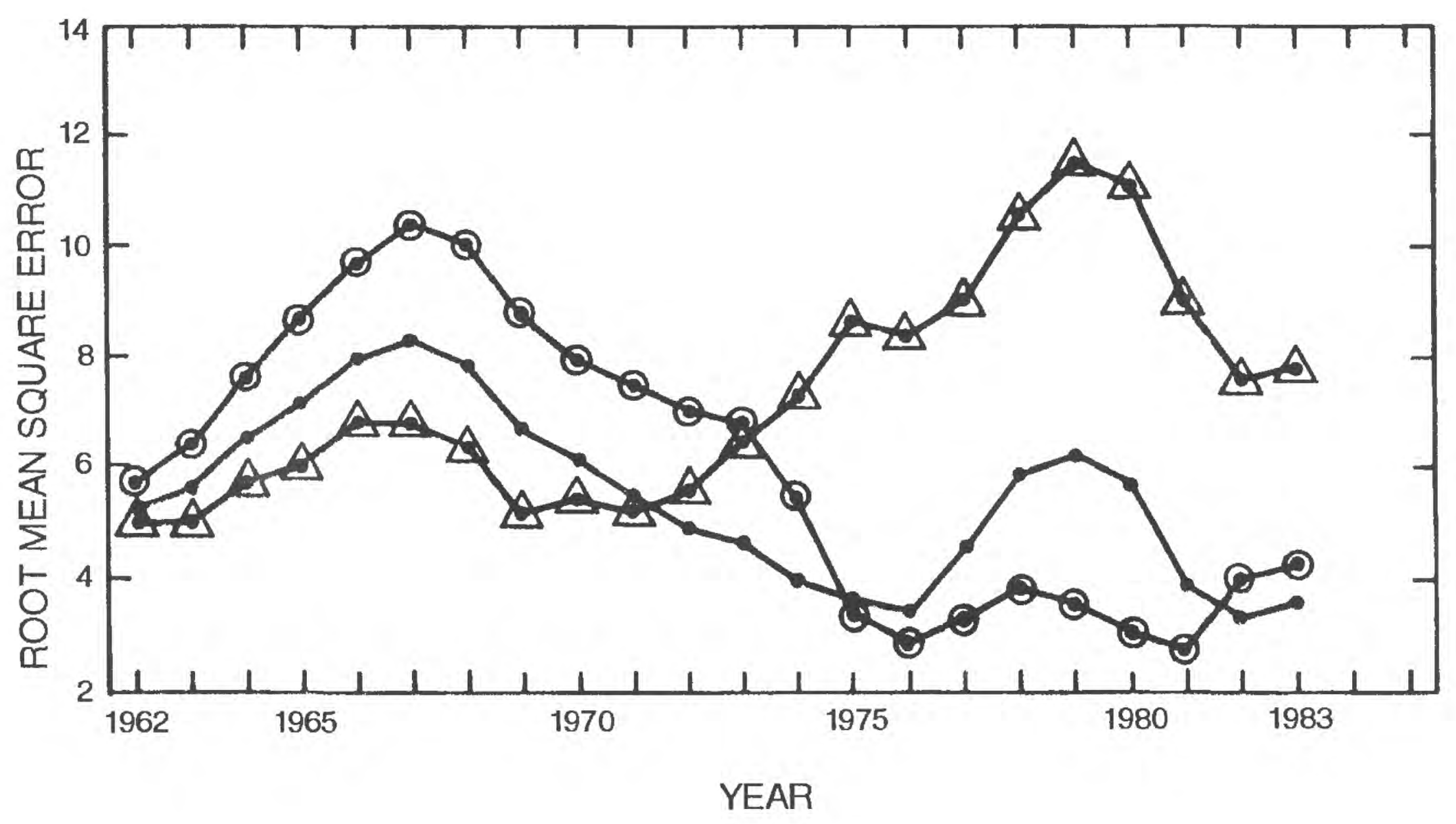

\section{EXPLANATION}

- Specific Yield $=0.15$ (used in model)

(-) Specific Yield $=0.075$

A Specific Yield $=0.30$

Figure 15. Sensitivity of simulated heads to changes in the specific yield used in the model. 


\section{SUMMARY AND CONCLUSIONS}

The Ohio River Valley in the Louisville area was eroded by glacial meltwater and was later partly filled with glacial outwash sands and gravels. The glacial outwash is composcd mainly of sand and gravel with an average thickness of $100 \mathrm{ft}$ overlain hy silt and clay that ranges from 0 to $40 \mathrm{ft}$ thick. Lenses of clay and silt, that range in thickness and extent. occur throughout the aquifer. The direction of groundwater flow in the aquifer is from the casten valley wall toward the Ohio River and toward pumping wells. The aquifer was at stcady state in 1962 and again in 1983.

The alluvial aquifer reccives natural recharge from the following sources: (1) direct infiltration of precipitation through the floodplain; (2) subsurface flow from the consolidated rocks along the valley walls and upward from the limestone bedrock; (3) flow from small streams; and (4) flow from the Ohio River to the aquifer when the stage of the river is higher than the adjacent ground-water levels. Humanrelated recharge occurs from induced flow from the Ohio River to pumping wells near the Ohio River and from sewage effluent to the water table in unsewered areas where septic systems are still in use. Discharges from the alluvial aquifer occur by flow to the Ohio River and pumping wells.

A two-dimensional, finite-clement model of the alluvial aquifer was calibrated by comparing the computed hydraulic heads with corresponding measured water levels for both steady-state and transicnt conditions. Steady-state conditions were assumed to occur in November 1962 and November 1983. Transient conditions were simulated for 1962-83. Ground-water withdrawals in 1962 were nearly three times greater than those of 1983 . The simulated water budget for 1983 steady-state conditions indicated that precipitation provided 42.6 percent of recharge to the aquifer, flow from the Ohio River provided 17.8 percent, and lateral flow from the eastem valley wall to the alluvium provided 18.2 percent. Upward flow from limestone bedrock to the alluvium and recharge from scptic tanks in unsewered areas accounted for the remaining 21.4 percent. Flow from the alluvial aquifer to the Ohio River was 67.3 percent of the total discharge and ground-water withdrawal was 32.7 percent.

Results of the transient simulation for the period heginning November 1962 and ending November 1983 indicated that the transient water-table fluctuation from 1962 to 1983 was primarily in response to a decrease in withdrawals. The transient simulation also confirmed previously published values of specific yield.

A two-dimensional finite-element calibrated model was used to simulatc our understanding of the hydrogeologic conditions in the area; however, due to assumptions and uncertainty in boundary conditions, water-level data, and estimated parameter values, a quantitative expression of the accuracy of the model cannot be given. The simulations in this report were designed on the basis of general hydrologic conditions. Results of the simulations only provide an estimate of the components of the ground-water budget in the alluvial aquifer and are not intended for wellfield design or placement. Additional investigations are needed for the alluvial aquifer in the Louisville area. The importance of interaction between the recharge and discharge components of the model warrant investigation utilizing multidimensional state of the art ground-water flow models relating to stream-aquifer interaction. In addition, water-quality components may be evaluated with the use of solute-transport models. 


\section{REFERENCES CITED}

Barker, R.A., Dunlap, L.E., and Saver, C.G., 1983, Stream-aquifer hydrology, Arkansas River valley, southwestern Kansas: U.S. Geological Survey Water-Supply Paper 2200, 59 p.

Bear, Jacob, 1979, Hydraulics of ground water: McGraw-Hill, Inc., 568 p.

Bell, E.A., 1966, Summary of hydrologic conditions of the Louisville area Kentucky: U.S. Geological Survey WaterSupply Paper 1819-C, 36 p.

Cooley, R.L., 1992, A MODular Finite-Element model (MODFE) for areal and axisymmetric ground-water flow problems, Part 2-Derivation of finite-element equations and comparisons with analytical solutions: U.S. Geological Survey Techniques of Water-Resources Investigations, book 6, chap. A4, 108 p.

Faust, R.J., and Lyons, B.E., 1989, Ground-water levels in the alluvial aquifer at Louisville, Kentucky, 1987-88: U.S. Geological Survey Water-Resources Investigations Report 89-4119. 15 p.

Faust, R.J., and Lyverse, M.A., 1987, Ground-water levels in the alluvial aquifer at Louisville, Kentucky: U.S. Geological Survey Water-Resources Investigations Report 87-4197. 18 p.

Freeze, R.A., and Cherry, J.A., 1979, Groundwater: Englewood Cliffs, N.J., Prentice-Hall, Inc., 604 p.

Guyton, W.F., 1944, Artificial recharge of ground-water reservoir with water from city's surface supply at Louisville. Kentucky: Kentucky Department of Mines \& Minerals Geological Division, 22 p., 6 pl.

Guyton, W.F., and Sublett, W.F., 1944, Conservation of ground water in the Louisville arca, Kentucky: Kentucky Department of Mines \& Minerals Geological Division, 22 p., 4 pl.

Hamilton, D.K., 1944, Ground water in the bedrock beneath the glacial outwash in the Louisville area, Kentucky: Kentucky Department of Mines \& Minerals Geological Division, 22 p.

Heath, R.C., 1983, Basic ground-water hydrology: U.S. Geological Survey Water-Supply Paper 2220, 84 p.

Kepferle, R.C., 1972, Geologic map of the Valley Station quadrangle and part of the Kosmosdale quadrangle, northcentral Kentucky: U.S. Geological Survey Geologic Quadrangle Map GQ-962, scale 1:24,000, 1 shcet.

1974a, Geologic map of parts of the Jeffersonville, New Albany, and Charlestown quadrangles. KentuckyIndiana: U.S. Geological Survey Geologic Quadrangle Map GQ-1211, scale 1:24,000, 1 sheet.

1974b, Geologic map of the Louisville East quadrangle, Jefferson County, Kentucky: U.S. Geological Survey Geologic Quadrangle Map GQ-1203, scale 1:24,000, 1 sheet.

Kernodle, J.M., and Whitesides, D.V., 1977, Rising ground-water level in downtown Louisville, Kentucky 1972-77: U.S. Geological Survey Water-Resources Investigations Report 77-92, 24 p.

Palmquist, W.N., Jr., and Hall, F.R., 1960, Availability of ground water in Bullitt, Jefferson, and Oldhan Counties, Kentucky: U.S. Geological Survey Hydrologic Investigations Atlas HA-122, scale 1:125,000, 3 sheets.

Price, W.E., Jr., 1964a, Map of fence diagrams of alluvial deposits along the Ohio River between Prospect and southwestern Louisville. Kentucky: U.S. Geological Survey Hydrologic Investigations Atlas HA-130, scale $1: 24,000,2$ sheets.

1964h, Map of geology and hydrology of alluvial deposits along the Ohio River between southwestern Louisville and West Point, Kentucky: U.S. Geological Survey Hydrologic Investigations Atlas HA-111, scale l: $250,000,2$ sheets.

Rorabaugh, M.1., 1946a, Inventory of water wells, Louisville area: City of Louisville and Jefferson County, Ky., 35 p., $1 \mathrm{pl}$.

1946b, Ground-water resources of the southwestern part of the Louisville area, Kentucky: U.S. Geological Survey, Unnumbered Open-File Report, 39 p. 
1948, Ground-water resources of the northeastern part of the Louisville area, Kentucky: City of Louisville, Louisville Water Company, $77 \mathrm{p}$.

1949. Progress report on the ground-water resources of the Louisville area, Kentucky, 1945-49: City of Louisville and Jefferson County, Ky.. 64 p.

1956, Ground water in northeastern Louisville, Kentucky, with reference to induced infiltration:

U.S. Geological Survey Water-Supply Paper 1360-B, 169 p.

Rorabaugh, M.I., Schrader, F.F., and Laird, L.B., 1953, Water resources of the Louisville area. Kentucky and Indiana: U.S. Geological Survey Circular 276, 49 p.

Starn, J.J., and Mull, D.S., 1994, Annotated hibliography of selected references on ground-water resources and geohydrology of the Louisville area, Kentucky, 1944-93: U.S. Geological Survey Open-File Report 94-75, 19 p.

Torak, L.J., 1992. A MODular Finite-Element model (MODFE) for areal and axisymmetric ground-water-flow problcms, Part I--Model description and user's manual: U.S. Geological Survey Open-File Report 90-194, 153 p.

1993a, A MODular Finite-Element model (MODFE) for areal and axisymmetric ground-water-flow problems, Part 1-Model description and uscr's manual: U.S. Geological Survey Techniques of Water-Resources Investigations. book 6, chap. A3, 136 p.

1993b, A MODular Finite-Element model (MODFE) for areal and axisymmetric ground-water flow probleıns, Part 3-Design philosophy and programming details: U.S. Geological Survey Techniques of Water-Resources Investigations, book 6, chap. A5, $243 \mathrm{p}$.

U.S. Department of Agriculture, 1966, Soil survey of Jefferson County, Kentucky: Soil Conservation Service, 137 p.

U.S. Department of Commerce, 1980, Census of population: Bureau of the Census, ser. p.c. 80-A19, 45 p.

1987, National Oceanic and Atmospheric Administration, climatological data, annual summary, Kentucky: v. 82 , no. 13 .

U.S. Environmental Protection Agency, 1981, Environmental Impact Statcment, Mill Creek area, Jefferson County, Kentucky: U.S. Environmental Protection Agency. 230 p.

U.S. Geological Survey, 1987, Water resources data, Kentucky water year 1987: U.S. Geological Survey Water-Data Report KY-87-1, 356 p.

Walker, W.H., 1961, An aquifer test in the southwestern part of the Louisville area, Kentucky: U.S. Geological Survey Unnumbered Open-File Report, 41 p.

Whitesides, D.V., Faust, R.J., and Zettwoch, D.D., 1983, Problems of rising ground-water levels in urban areas with special reference to the Louisville, Kentucky area: U.S. Geological Survey Water-Resources Investigations Report 83-4233, 26 p. 